\title{
CONTRIBUTION TO THE GEOLOGY AND GEOCHEMISTRY OF THE OUTOKUMPU REGION
}

\author{
Aarto Huhma and Majja Huhma \\ Exploration Department, Outokumpu Company, Outokumpu, Finland
}

\section{INTRODUCTION}

This paper is divided into two parts. The first part deals with the geology of North Karelia and the second part with some aspects of the geochemistry pertinent to the Outokumpu region. Thus, the former serves as an introduction to the latter.

Detailed geological maps are prerequisites for prospecting. Excluding the map of the Outokumpu ore field (Vähätalo, 1953) no reliable geologic maps have been available concerning the Outokumpu region. The only map covering the whole area is the old map sheet of Joensuu on a scale of $1: 400$ 000, for which the investigations in the field were brought to an end during the first half of the 1910's. The map was published at the beginning of the 1920's (Frosterus and Wilkman, 1920). Two outstanding studies on the area have been published, but they do not include any detailed maps (Haapala, 1936, Väyrynen, 1939).

To eliminate this drawback, the Exploration Department of the Outokumpu Company commenced the remapping of the region in great detail in the 1950's and the work continued until 1967.

During the last few years the Exploration Department has intensified the prospecting for new ore deposits analogous with the Outokumpu deposit. Special attention has been focused on the rock assemblage in which the Outokumpu ore body is situated. This assemblage, the Outokumpu zone, is characterised by serpentinites, quartzites, carbonate rocks and skarns.

The Outokumpu copper ore is cobalt and nickel-bearing. According to Vähätalo (1953) the ore contains relatively abundant cobalt $(0.2$ per cent), while the amount of nickel is about half of that $(0.1$ per cent). The presence of these metals has also been well-known in the copper deposit of Luikonlahti nearby and the showings of copper found more recently in similar geologic frames have invariably proved to contain cobalt and nickel.

However, in connection with the exploration of the past ten years sulphide mineralizations of another type have been recognized in the same geologic surroundings. In contradistinction to the copper-cobalt ores, they are characterized by predominance of nickel and by the lack or scarcity of copper and cobalt.

It is also characteristic of the serpentinitequartzite formations that their sulphide phase is nickel-predominant. The nickel to cobalt ratio is similar to that of the ultrabasic rocks, i.e. Ni : Co from 23 to 25 (Häkli, 1963). The copper content is fairly low.

Impetus for the present geochemical investigations was given by these findings. The question 
was raised as to whether eventual anomalous copper and cobalt tenors of the sulphide phase present in the country rocks would signify nearness of cobaltiferous copper ores or at least indicate favorable horizons. The application of this idea to exploration was carried out in terms of a regional cobalt programme. The work soon led to a discovery at Vuonos, a location explored earlier by shallow drill holes, about $6 \mathrm{~km}$ northeast of Outokumpu where drilling of a coppercobalt anomaly traversed a blind orebody of the Outokumpu type. This discovery can be attributed partly to the cobalt programme but also partly to the general knowledge concerning the structure of the bedrock. 


\title{
PART I
}

\section{SHORT DESCRIPTION OF THE GEOLOGY OF THE OUTOKUMPU DISTRICT}

\author{
by
}

Aarto Huhma

\begin{abstract}
The paper deals briefly with the geology of the Outokumpu region. Special attention is paid to the aspects the investigations of the last ten years have brought with, e.g. to the tectonics as well as to the petrology of the serpentinite zone with the associated quartzites, carbonate rocks and skarns. Quartzites are considered of not being clastic sediments but rather colloidal silica precipitates. A metasomatic origin is proposed for the carbonate rocks, and skarns are interpreted as having formed through a reaction between carbonate rocks and quartzites. The differences between the rocks in association of serpentinites and quartzites, carbonate rocks and skarns of the epicontinental facies of the region are discussed.
\end{abstract}

\section{CONTENTS}

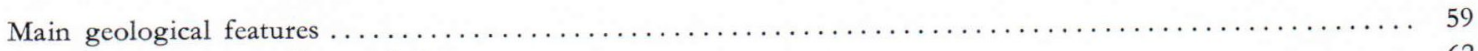

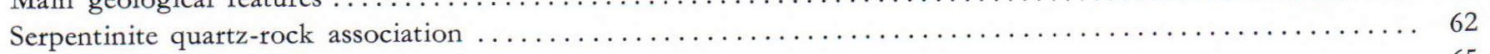

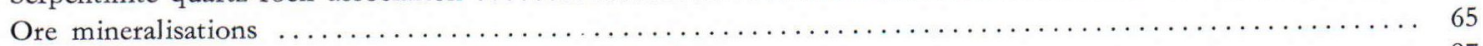

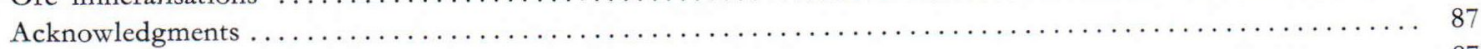

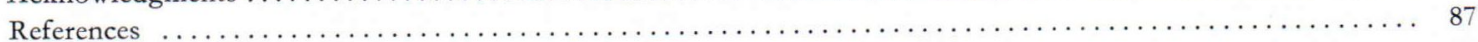

\section{Main geological features}

The area in question is situated in North Karelia, in eastern Finland. Its location can be seen in Fig. 1.

The bedrock of the area is Precambrian and composed of rocks of two different ages. The age of the older, the Prekarelian, is about 2700 my and of the younger, the Karelian, about 1800 my (Kouvo, 1958).

In Fig. 2, the Prekarelian rocks are marked in grey, the rest of the map consisting of Karelian rocks.
In the east, the Karelian rocks border in a fairly rectilinear manner on the extensive eastern Prekarelian craton area which continues uninterrupted over the frontier into the USSR. In the north, the Karelian rocks are interfingered with the Prekarelian rocks. In the Karelian rock area, the Prekarelian rocks are exposed as many separate domes. Well-known domes are those of Sotkuma, Kontiolahti, Liperinsalo and Oravisalo. In connection with recent mapping, five new domes have been discovered to the west, in the Juojärvi area. The present author has called these the Juojärvi domes. 


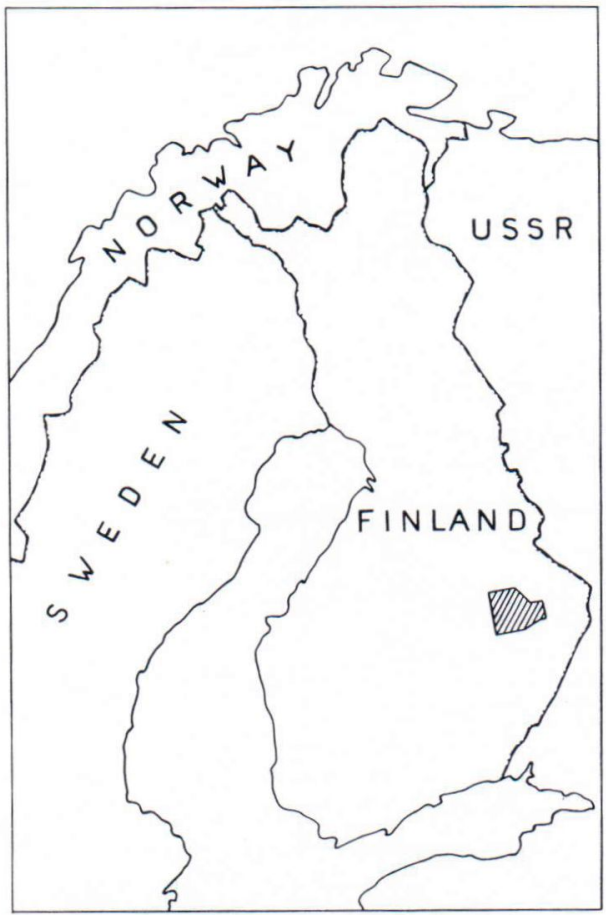

Fig. 1. Location of the area investigated.

For the most part, the Prekarelian rocks are gneisses, usually granodioritic in composition. However, they contain amphibolites, which in places occur abundantly as sills in the gneisses.

The Prekarelian rocks form the sedimentation basement for the Karelian sedimentary rocks. In many places conglomerates and other basal rocks are encountered at the edges of the Prekarelian rocks.

Karelian sediments of the epicontinental facies border on the Prekarelian rocks. To these sediments belong arenites, skarn rocks (calc-silicate rocks) and carbonate rocks as well as black schists.

In the eastern and northern part of the area the epicontinental sediments form rather thick conform layers, but westwards the thickness of the layers decreases and various types of sediments alternate frequently even as very thin layers.
Orthoquartzites, feldspar-bearing quartzites and arkosites as well as a certain amount of micarich quartzite schists belong to the arenites.

The quartzites and conglomerates on the northern side of the Kontiolahti dome have been interpreted by G. Gaál (1964) as Karelian molasses.

The skarn rocks are characterised by diopside and/or actinolite. The third major component is feldspar (usually plagioclase). In addition, there is often biotite in the actinolite-bearing rocks.

The carbonate rocks are layered dolomitecalcite rocks.

Most of the Karelian sediments are mica gneisses and phyllites which deposited into the geosynclinal furrow and which in places contain abundant black schist intercalates. Phyllites only occur in the eastern part of the area. Westwards, the rock type grades into mica gneiss and right at the western edge of the area the rock resembles veined gneiss.

A distinct increase westward in the degree of metamorphosis can be observed. The increase is not, however, strictly linear. In the eastern part of the area, phyllites and mica gneisses occur as alternating zones. A similar mode of occurrence has been observed with regard to the veined gneisses and mica gneisses in the western part of the area.

Amphibolites and serpentinites belong to the Karelian initial magmatites. The amphibolites occur in the sediments of the epicontinental facies, and the serpentinites in the sediments of the geosynclinal facies.

In the western part of the area, late-orogenic Karelian intrusive rocks are abundant forming a differentiation series ranging from diorites to granodiorites and granite-pegmatites (the socalled Maarianvaara granite). The mode of occurrence of the Maarianvaara granite is both concordant and cross-cutting so that on a large scale it is concordant but on a small scale it is often crosscutting. Granite and pegmatite veins also cut ores, e.g. at Luikonlahti and Outokumpu. 


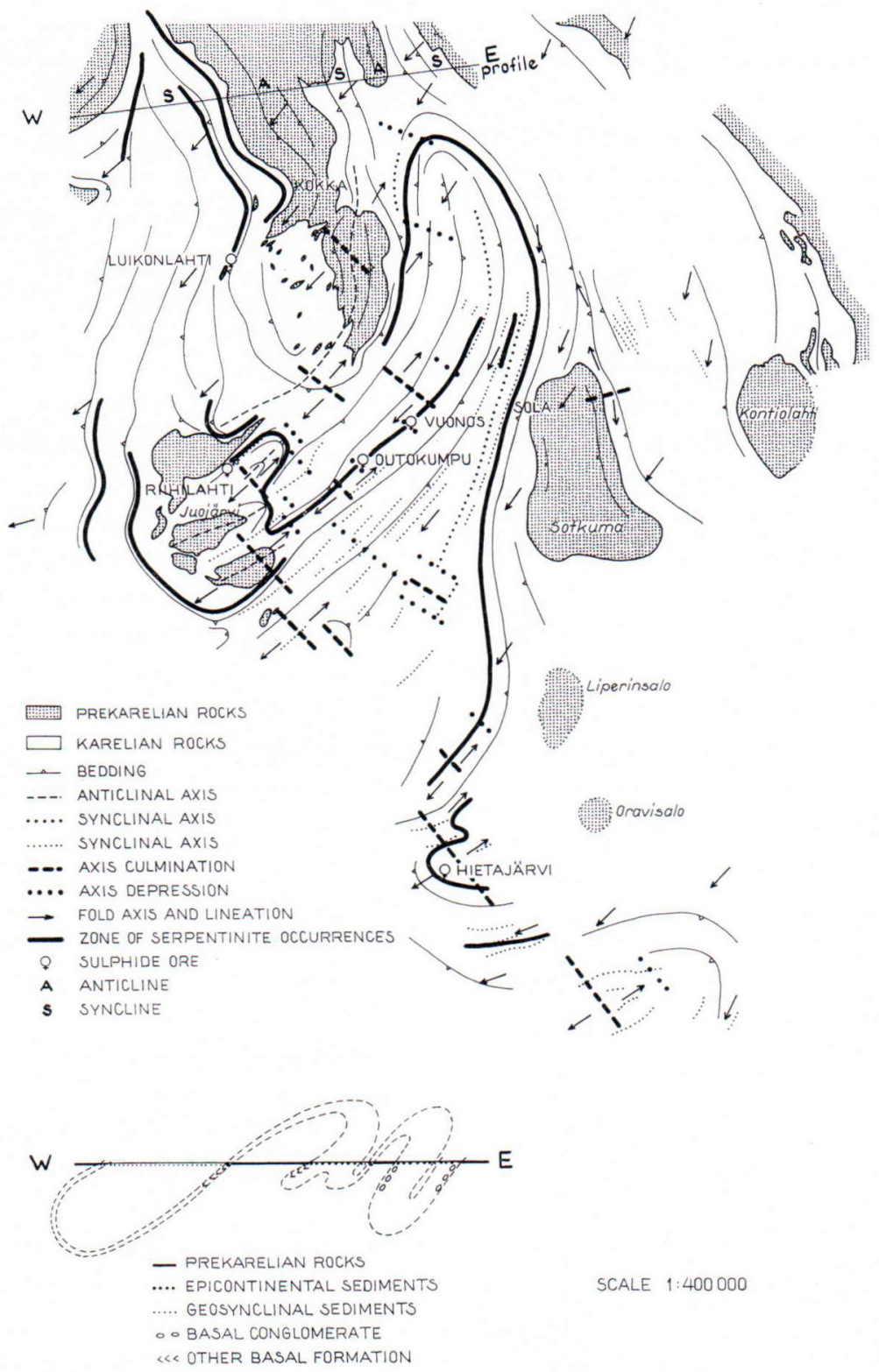

Fig. 2. Tectonic map and profile.

Some dyke rocks in the western part of the area are younger than the Maarianvaara granite. Their mineral composition is that of fine-grained plagioclase-biotite-quartz rocks.

In addition to the abovementioned dyke rocks, lamprophyre dykes, which have been known for decades (Hackman, 1914), are encountered within a limited area at Niinivaara, Kaavi. The dykes are rectilinear and rather narrow (some tens of centimetres) and run perpendicular to the tectonic B-axis.

In the eastern part of the area, north of the Kontiolahti dome, diabase dykes are encountered in arenites. 
The strike of schistosity and bedding in the Karelian sedimentary rocks is predominantly NW-SE and the dip SW. In the northern part of the area, where the Karelian rocks occur as fingers inbetween the Prekarelian rocks, the folding is isoclinal and the plunge invariably towards the SW with the consequence that the Karelian sediments are alternately the right-sideup and overturned (Fig. 2).

The mode of folding changes southwards. The Juojärvi domes and the Maarianvaara granite have an anticlinal axis which causes the bedding and schistosity of the Karelian sediments to dip westwards on its western side, southwards on the southern side and eastwards on the eastern side, i.e. the bedding of the sediments encircles these areas.

There is a syncline between the Juojärvi domes and the dome of Sotkuma. This is not a single syncline but an extensive synclinorium.

The fold axis and lineation plunge predominantly towards the SW. However, the Juojärvi domes and the Maarianvaara granite have axial culminations causing the axis to plunge to the NE. There is a succession of several axial culminations and depressions with the consequence that, in this area, the axis plunges alternately to the SW and NE (Fig. 2).

\section{Serpentinite quartz-rock association}

Serpentinites occur in mica schist as a conform zone following the bending of the mica schist around the Prekarelian domes. The zone is by no means coherent. In some places, as e.g. in the Outokumpu area, where serpentinite is encountered as a narrow and coherent lens many kilometres in length the zone is very distinct. In some other places, the existence of the zone can be established only on the basis of small scattered serpentinite lenses occupying a certain horizon around the Prekarelian domes.

In the serpentinite zone, the massifs occur in mica schist, generally in connection with black schist intercalates. The serpentinite zone is not always composed of a single row of lenses, but two or even more parallel lenses may occur separated from each other by mica gneiss.

The size of the serpentinite lenses varies a great deal. At Outokumpu, the largest lenses are a few hundred metres in width and several kilometres in length, but lenses have also been encountered which measure only some tens of metres in length.

Serpentinites are monomineral serpentine rocks. However, they almost always contain variable amounts of magnetite as a fine dust whose abundance frequently determines the colour of the rock. In the western part of the area, a mesh structure chrysotile is the major serpentine mineral, whereas in the eastern part antigorite predominates.

In addition to serpentines and magnetite dust, some chlorite (clinochlore-sheridanite) is almost always encountered. In places it occurs as chlorite-schist zones in the serpentinites.

Relict structures can often be observed in the serpentinites especially in the west. Pseudomorphs after olivine are the most common but also amphibole pseudomorphs are frequent. Pseudomorphs after pyroxene are less common.

Olivine is encountered occasionally in very dark types. Pyroxene (enstatite, augite) is also met with in them as well as amphibole (tremolite, antophyllite) which is the most common of the preserved minerals.

Besides the abovementioned minerals, carconate, talc and kaemmererite are also observed. In addition to magnetite, there are chromite, pyrrhotite, pentlandite, machinawite (Kouvo et al., 1963) and graphite.

A gravity low coincides with the great massifs. This is due to the low density of the serpentinites (from 2.4 to 2.6 compared with that of the environment (from 2.6. to 3.0). This applies above all to the chrysotile serpentinites. The antigorite serpentinite is heavier (from 2.6 to 2.7). The pale serpentinites containing only small amounts of other minerals are the lightest. 
Originally, the serpentinites were dunites which also included pyroxenitic and peridotitic variants.

Quartzites, skarns and carbonate rocks occur in association with the serpentinites. These differ from the quartzites, skarns and carbonate rocks of the epicontinental facies. The Outokumpu quartzites always occur together with the large serpentinite bodies and the larger the bodies are, the thicker are also the quartzites. In general, no quartzites are encountered in connection with the small separate serpentinite bodies.

Quartzites occur at the borders of the serpentinites either as zones parallel to the serpentinite bodies or pinching into them. The quartzites are not in immediate contact with serpentinites but there are skarns and carbonate rocks inbetween.

In most of the cases, the quartzites are bordered on one side by the black schists of the serpentinite zone. In their purest form, the quartzites are almost monomineral quartz rocks. However, they often contain diopside and tremolite (in the eastern part of the area only tremolite) and the variants range from pure quartzites to skarns.

In general, the quartzites are schistose and the skarn minerals occur as narrow bands or wider zones parallel to the schistosity. Between the bands and zones, zones of pure quartz are encountered. The quartzites are usually pale grey in colour. The skarn-bearing quartzites are greenish and the quartzites containing graphite and/ or sulphide dust dark grey or even nearly black in colour.

A spare sulphide dissemination is common. In addition to pyrrhotite and pentlandite, the quartzites contain pyrite, less often sphalerite, chalcopyrite and cobalt-pentlandite (Kouvo et al., 1959). A zinc-bearing chromite is a frequent oxide. [Vuorelainen (1962, personal communication) was the first to call attention to the occurrence of a zinc-bearing chromite which was later studied by Thayer and Weiser (Thayer et al.,1964, Weiser, 1967).] Carbonate is observed occasionally.

Besides quartz, diopside and tremolite only small amounts of other silicates are encountered.
They are uvarovite, chrome epidote, chrome tourmaline, fuchsite, phlogopite and chlorite. The local layering in the quartzites is attributed to the alternation of coarse- and fine-grained beds. The latter are often darker in colour than the former. The dark colour is due to the very fine-grained sulphides, graphite and/or zincbearing chromite. The microscopic texture is granoblastic.

These quartzites differ from those of the epicontinental facies in the following respects.

1. They are devoid of feldspars, muscovite and biotite. These minerals make their appearance in the quartzite only when the quartzite grades into black schist (quartz-rich black schist). No clastic features have been observed.

2. These quartzites do not contain heavy minerals (zircon, rutile, apatite), which are invariably present in the quartzites of the epicontinental facies.

3. The local banding is not due to the compositional variation in the silicatic portion of the quartzite, but rather is caused by a fine sulphide, graphite or oxide dust.

4. These quartzites are met with only in association with the serpentinites and the larger are the serpentinite bodies, the thicker are also the quartzites.

5. The average nickel content is about 0.2 per cent whereas in the quartzites of the epicontinental facies it is about 0.002 per cent or even less. Similarly, the former contain about 0.01 per cent Co and the latter less than 0.001 per cent Co (Fig. 3).

According to the interpretation of the present author, these rocks are not to be considered as quartzites at all.

The carbonate rocks in association with the serpentinites occur in the immediate contacts of the serpentinites. In the western part of the area, they are dolomite but in the east magnesite. The serpentinites grade gradually into carbonate rocks. In their purest forms the rocks are pale grey in colour, homogenous and equigranular. They often contain tremolite. Other minerals are 


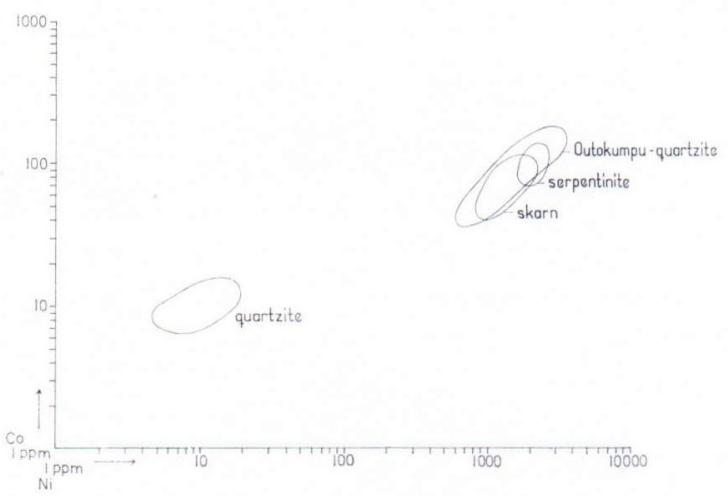

Fig. 3. Most common abundances of nickel and cobalt in serpentinites, skarns and quartzites in association with serpentinites (»the Outokumpu quartzite»), and in the quartzites of the epicontinental facies.

mica (light or green, chrome-bearing), serpentine, chlorite, chromite, pyrrhotite, pentlandite and occasionally gersdorfite. In places, considerable amounts of talc are encountered even giving rise to occasional talc schists.

These carbonate rocks differ from those of the epicontinental facies in that the bedding is often lacking and that they do not contain calcite but are either dolomite or magnesite rocks. Further, the carbonate rocks of the epicontinental facies are devoid of pentlandite as well as chromite and other chrome-bearing minerals. Accordingly, the present author does not consider these rocks either as sediments.

Between the quartzite and the carbonate rock which is associated with serpentinite, green skarns, such as chrome-bearing diopside, diopside-tremolite and tremolite rocks, are met with.

The diopside rocks usually border on the quartzites but they also occur as intercalates in the latter. The tremolite rocks border on carbonate rocks. A continuous set of variants exists ranging from quartzites to skarn rocks as well as from carbonate rocks to tremolite rocks. A complete set is as follows: serpentinite - carbonate rock - tremolite-bearing carbonate rock - skarn - diopside-bearing quartzite - quartzite.
In general, the skarn rocks occur conformably with regard to quartzite, and their width varies from a few centimetres to several tens of metres.

It is fairly common for small amounts of carbonate and quartz to occur in skarn rocks. Characteristic are the chrome-bearing minerals uvarovite, chromite and eskolaite (Kouvo and Vuorelainen, 1958) even though they are not always present. Uvarovite occurs especially in diopside skarns while eskolaite prefers tremolite skarns.

Pyrrhotite and pentlandite can be observed almost invariably. Sometimes gersdorfite, pyrite and chalcopyrite are also encountered, as is also graphite. Small amounts of uraninite have been estsblished.

The skarn zones may reach considerable dimensions. Coherent skarn formations are known of 35 metres in width, whose length exceeds three kilometres.

These skarn rocks differ from those of the epicontinental facies for the following features:

1. Feldspar is lacking, as is also biotite.

2. The chrome and nickel percentages are about twenty times higher than in the skarns of the epicontinental facies.

The rock association serpentinite - carbonate rock - skarn - quartzite is so similar and regular everywhere that its mode of occurrence indicates a genetic relation between its component rocks.

If the quartzites occuring in association with the serpentinites (the so-called »Outokumpu quartzites») are compared with the arenates of the epicontinental facies, it is observed that they differ from each other with regard to their mode of occurrence, structure, mineral composition and chemical composition (Fig. 3). Consequently, the present author holds the opinion that the "quartzites» associated with the serpentinites are not clastic sediments but chemical colloidal silica precipitates which were formed through the action of the intruding ultramafic magma, serpentinisation and carbonatisation and were later metamorphosed into rocks resembling 
quartzites. These rocks may be called tentatively quartz rocks.

Neither does the present author consider the carbonate rocks associated with the serpentinites as sediments but as rocks of metasomatic origin (Haapala, 1936).

The skarns which occur in association with the serpentinites were formed through the reaction between the quartz and the carbonate rocks.

\section{Ore mineralisations}

Ore mineralisations of two types, i.e. coppercobalt and nickel mineralisations occur in the quartz rocks and the skarns associated with the serpentinites.

\section{Copper-cobalt mineralisations}

The sulphide minerals characteristic of the copper-cobalt mineralisation are chalcopyrite and cobalt pentlandite. The iron sulphides, pyrite and/or pyrrhotite, are abundant. In addition, sphalerite occurs frequently.

The mineralisation is encountered most often in quartz rocks but in places also in skarns and carbonate rocks.

The most well-known copper-cobalt mineralisation is the Outokumpu ore. Others are Luikonlahti, Vuonos, Riihilahti and Hietajärvi (Fig. 2).

\section{Nickel mineralisations}

The sulphides characteristic of nickel mineralisations are disseminated pyrrhotite and nickel pentlandite. This type of mineralisation is common in the skarn rocks, quartz rocks and carbonate rocks associated with the serpentinites.

The best known nickel mineralisation is the Kokka prospect (Fig. 2). The rock sequence is as follows: serpentinite - skarn - black schist - mica gneiss.

In general, the black schists are rich in sulphides, which, however, are mainly iron sulphides (pyrrhotite and pyrite). Minor amounts of sphalerite and chalcopyrite are common in places, though.

Pentlandite and pyrrhotite are the sulphides in the skarns. Occasionally, gersdorfite, pyrite and chalcopyrite are met with. Whenever serpentinites contain sulphides they are rich in pentlandite.

In the Kokka prospect, the variation of the sulphur and nickel contents has been investigated in the rocks from black schists through skarns to serpentinite (Fig. 4).

Sulphur content reaches a maximum in the black schist near the contact against skarn. In the skarns, it drops abruptly and remains low throughout this rock even decreasing a little in the serpentinites. The black schists show a low nickel content which increases near the contact of the skarn and rises steeply in the skarns to drop again down to the constant value in the serpentinites.

The occurence of nickel-bearing skarns in the contacts of the serpentinites indicates a genetic relationship between the skarns and the serpentinites. The formation of a nickel mineralisation between serpentinite and the black schist rich in sulphides has a bearing on the skarnification. The nickel in the skarns clearly originates from serpentinites which is further indicated by the nickel to cobalt ratio (23-25) (Häkli, 1963). The enrichment of nickel in skarns can obviously be attri-

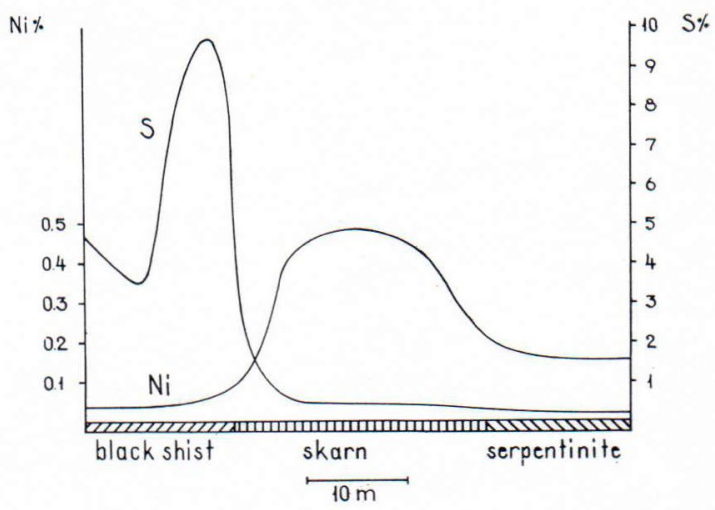

Fig. 4. Relation between sulphur and nickel in the Kokka deposit. 
buted to the fact that there was sulphur available in the black schist on the one side of the skarn to form nickel sulphide. The primary silicatic nickel incorporated in serpentinite (dunite) was transferred from the silicate phase into the sulphide phase.

The migration of sulphur from the black schists is also reflected in the iron sulphides of the black schists. Near the contact against the skarn they are of pyrrhotite even though otherwise the pyrite is a predominant iron sulphide.

The location of the sulphur maximum in the contact between black schist and skarn is due to the fact that the contact was enriched in heavy metals from the black schist, such as iron, zinc and copper, which as pyrrhotite, sphalerite and chalcopyrite increase the sulphur content. 
PART II

\title{
NICKEL COBALT AND COPPER IN SOME ROCKS OF THE OUTOKUMPU REGION
}

\author{
by \\ Majja Huhma
}

\begin{abstract}
The study is based on the diamond core material obtained through the prospecting activities carried out by the Outokumpu Company. The paper deals with the occurrence of nickel, cobalt and copper mainly in the rocks of the Outokumpu zone. The samples were analysed by the atomic absorption method. The normal and anomalous abundances of nickel, cobalt and copper in various rocks are described by means of $\mathrm{Ni}-\mathrm{Co}, \mathrm{Cu}-\mathrm{Co}$ and $\mathrm{Cu}-\mathrm{Co}-\mathrm{Ni}$ diagrams. Attention is focused on the anomalies produced by the ores of the Outokumpu type in their environments as well as on the influence of the environment upon the nickel to cobalt ratio in the ores.
\end{abstract}

\section{CONTENTS}

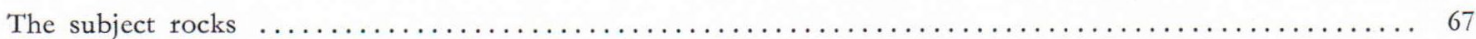

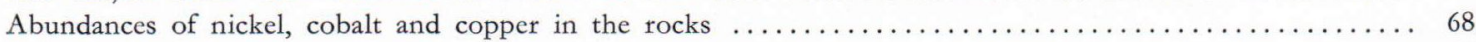

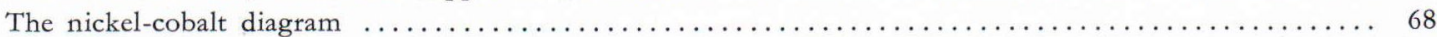

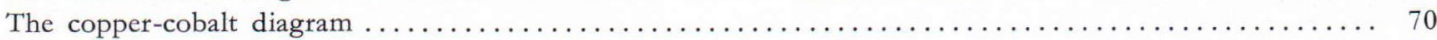

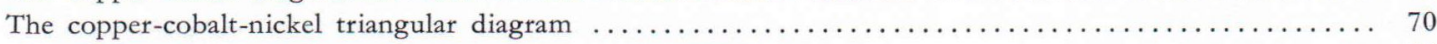

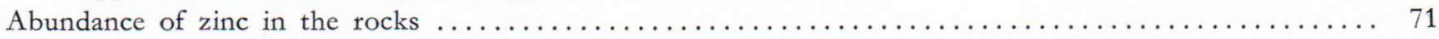

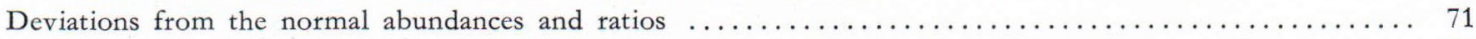

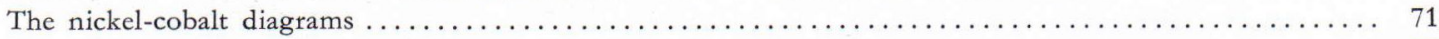

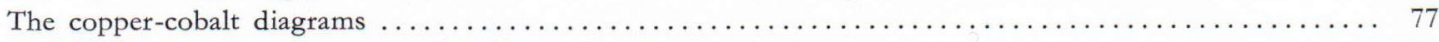

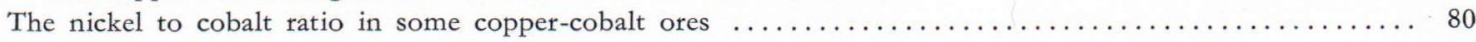

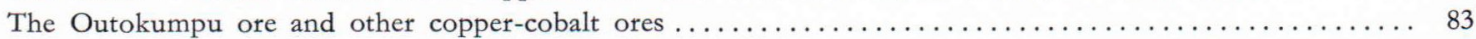

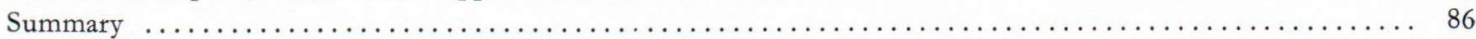

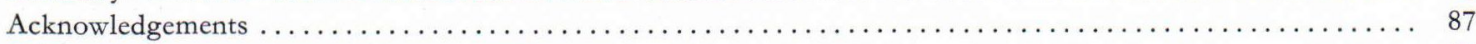

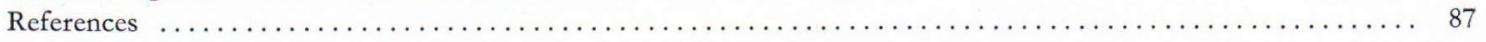

\section{The subject rocks}

The material for this study originates from the diamond drillings carried out in North Karelia during the last ten years in connection with the prospecting activities of the Outokumpu Co. The material was collected principally from the rocks occurring in zones of the Outokumpu types. These zones are composed of serpentinites, dolomites, skarns, quartzites and black schists. 
Samples from the mica gneisses surrounding the zones were also included to some extent. The cobaltiferous copper ores of the Outokumpu type play an important role in the present investigation. The present author has not carried out investigations in detail on the Outokumpu ore. However, a short survey of the ore is given and comparisons are drawn between it and the other ores discussed in this paper.

The drill cores from various prospects were sampled and analysed on the basis of the rock types. One half of the core, from 1 to 4 metres in length, was submitted to atomic absorption analysis. The samples were analysed for sulphidic copper, zinc, nickel and cobalt. The analytical data of copper, nickel and cobalt will be treated in the following. Zinc is discussed only briefly in connection with the general review.

The processing of the analytical data was carried out by grouping the rocks in the following way:

1. Serpentinite, chlorite and talc schist.

2. Quartzite-skarn-dolomite including nickel mineralisations.

3. Black schist.

4. Mica gneiss.

5. Copper-cobalt ore of the Outokumpu type.

On the basis of the analytical data, the Ni-Co and $\mathrm{Cu}-\mathrm{Co}$ diagrams were drawn as well as the $\mathrm{Cu}-\mathrm{Co}-\mathrm{Ni}$ triangular diagrams. With the aid of these diagrams the mode of occurrence of nickel, cobalt and copper in the rocks and prospects is discussed.

\section{Abundances of nickel, cobalt and copper in the rocks}

The nickel-cobalt and copper-cobalt diagrams (Figs. 5 and 6) were constructed on the basis of the analytical data. The principal abundance fields for different rocks are marked on the diagrams.

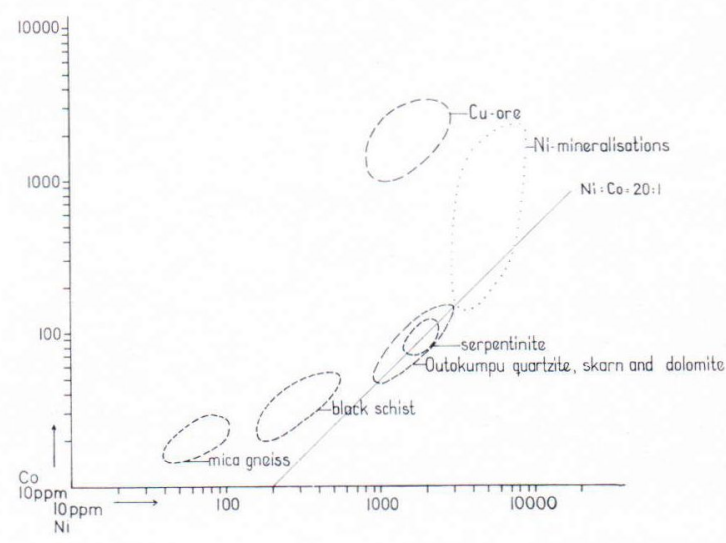

Fig. 5. Ni-Co diagram. The normal concentration fields for the rocks of the Outokumpu type.

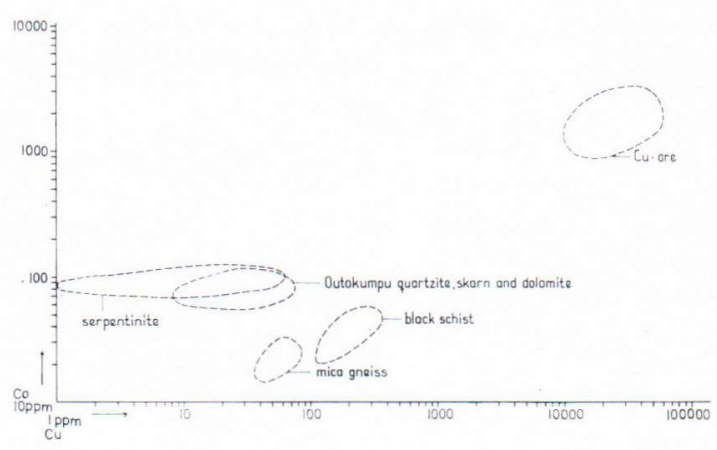

Fig. 6. $\mathrm{Cu}-\mathrm{Co}$ diagram. The normal concentration fields for the rocks of the Outokumpu type.

\section{The nickel-cobalt diagram}

The serpentinites in the Outokumpu area (Haapala, 1936) are poor in sulphides. Only seldom can sulphides be observed with the naked eye for the sulphur percentage is frequently under 1.

However, the abundance of nickel is relatively high in serpentinites and usually varies from 1500 to $2200 \mathrm{ppm}$ (Fig. 5). The sulphides are rich in nickel and occasionally pentlandite is almost the only sulphide present.

The abundance of cobalt varies parallel to that of nickel. In the serpentinites, the nickel to cobalt ratio is fairly consistently $20: 1$, corresponding to that in the ultramafic rocks. In general the cobalt tenor in serpentinites is between 70 and 110 ppm. 
Zones of $\mathrm{chlorite}$ and $\mathrm{talc} \mathrm{schists}$ are encountered in association with the serpentinites. Also soapstones occur especially in the eastern part of the area. These rocks contain less nickel and cobalt than the serpentinites.

Quartzites, skarns and dolomites are encountered in association with serpentinites. They are not clearly distinguishible from each other everywhere and several gradational variants are encountered ranging from pure quartzites through skarn-bearing quartzites to skarns. These latter grade further through skarn-bearing dolomites into dolomites. Rocks of different gradational types were also analysed. Since in many cases it was confirmed that the abundance of cobalt and nickel in the three end members: quartzite, skarn and dolomite is the same, these rocks were treated as one group.

Like serpentinites the quartzites, skarns and dolomites are usually poor in sulphides. Consequently, the abundance of sulphur remains low in these rocks, generally being under one per cent i.e. on the same level as in the serpentinites.

The content of nickel in quartzites, skarns and dolomites is relatively high and pentlandite is the predominant sulphide. The resemblance to the serpentinites is obvious. However, the nickel tenor fluctuates within slightly larger limits. Usually the abundance of nickel ranges from 900 to $3000 \mathrm{ppm}$, the most common values being between 1000 and $2200 \mathrm{ppm}$. The higher tenors, from 2000 to $3000 \mathrm{ppm}$, are encountered especially in the skarns but also in the quartzites, whereas in the dolomites the high concentrations are less frequent.

As in the serpentinites the abundance of cobalt varies sympathetically with that of nickel. In general, the cobalt tenor varies from 50 to $120 \mathrm{ppm}$. The nickel to cobalt ratio is on an average $20: 1$.

The serpentinite and quartzite-skarn-dolomite fields occupy the same area on the diagram. The latter is somewhat larger due to the fact that the distribution of sulphides in these rocks is not as homogeneous as it is in serpentinites.
$\mathrm{B} \mathrm{lack} \mathrm{schist} \mathrm{is} \mathrm{an} \mathrm{omnipresent} \mathrm{constit-}$ uent in the Outokumpu zone (Peltola, 1960). In addition to graphite, the abundance of sulphides is a characteristic feature of the black schist and the sulphur tenor occasionally exceeds 10 per cent. Iron sulphides, pyrite and pyrrhotite, predominate in the sulphides. However, sphalerite and chalcopyrite can also be frequently observed macroscopically.

Considering the abundance of the sulphides, the black schists contain relatively little nickel and cobalt. The content of nickel fluctuates between 150 and 500 ppm and that of cobalt between 20 and $60 \mathrm{ppm}$, respectively. The nickel to cobalt ratio, which varies between $6: 1$ and $10: 1$, differs entirely from that of the serpentinites and quartzites. In the diagram the black schist forms its own field apart from those of the latter.

The $\mathrm{mica}$ gneis $\mathrm{s}$ is poor in sulphides and often no sulphides at all can be observed with the naked eye.

The abundance of nickel and cobalt is low in the mica gneiss. The nickel tenor varies from 40 to $90 \mathrm{ppm}$ and that of cobalt from 15 to 30 ppm. The sulphide species occur approximately in the same relative amounts as they do in the black schists. However, the nickel to cobalt ratio, i.e. 3-4:1 indicates that in the mica gneiss, nickel is slightly less predominant.

Only few samples collected from granites, pegmatites and aplites (the Maarianvaara granite) were analysed. The contents of nickel and cobalt are low in these rocks. The abundance of nickel fluctuates between 4 and $7 \mathrm{ppm}$ and that of cobalt between 3 and $5 \mathrm{ppm}$. The nickel to cobalt ratio is $1: 1-2: 1$.

The ore mineralis ations can be divided into two groups; the c o p p e r - c o b a l t o res of the Outokumpu type and the $\mathrm{nickel}$ $\mathrm{mineralisations.} \mathrm{An} \mathrm{area} \mathrm{is} \mathrm{marked} \mathrm{on}$ the diagram within which the concentration points of the ores of the Outokumpu type most often fall. These points form a field of their own clearly outside those of the other rocks. The 
abundance of nickel in this field is of the same order of magnitude as in the serpentinite-quartzite field, i.e. from 1000 to $2000 \mathrm{ppm}$, whereas the abundance of cobalt is on an average 20 times as high as that in the serpentinite-quartzite field, i.e. $1000-3000 \mathrm{ppm}$.

The nickel mineralisations encountered in quartzites, skarns and sometimes in dolomites contain about $3000-7000 \mathrm{ppm}$ nickel. Their cobalt content varies from 120 to $2500 \mathrm{ppm}$.

\section{The copper-cobalt diagram}

In connection with the serpentinites it was stated that serpentinites are poor in sulphides but contain, however, relatively abundantly nickel. Their nickel to cobalt ratio is approximately the same as in ultramafic rocks. It is also a characteristic feature of the serpentinites that the content of copper is very low. Often it is under $10 \mathrm{ppm}$ and occasionally even nil. In some places, the abundance of copper reaches somewhat higher values but in general it fluctuates between 1 and $60 \mathrm{ppm}$.

The copper tenor in the chlorite and talc schists as well as in the soapstones is of the same order of magnitude as that in the serpentinites.

The quartzites, skarns and dolo$\mathrm{mites}$ resemble serpentinites as far as the sulphides are concerned. Their copper content is also low, varying usually between 10 and 80 ppm. On the diagram (Fig. 6), the fields of both of these rock groups are horizontal. The variation in the copper tenor does not introduce a variation in the cobalt tenor but the latter fluctuates sympathetically with the concentration of nickel.

Anlike the former rocks, the bla ck s c his t is considerably richer in copper. Usually the copper content fluctuates between 100 and 400 ppm.

The content of copper in the sulphide-poor $\mathrm{mica} \mathrm{gneiss}$ is lower than in the black schists. In the mica gneisses there are equal amounts of copper and nickel varying from 40 to $90 \mathrm{ppm}$. The copper tenor in the granites is low, approximately $10 \mathrm{ppm}$ or even less.

For various reasons it can be anticipated that the $\mathrm{Cu}$-Co points of the copper ore will form a field on the diagram apart from those of the other rocks. The abundance of copper in the ore has increased a hundredfold compared with that in the black schist, which is the rock richest in copper outside the ore. The concentration of cobalt in the ore exceeds that in the serpentinitequartzite association by 20 , as shown by the nickel-cobalt diagram.

The copper contents of the $\mathrm{nickel} \mathrm{min}$ e r a lis a tions vary. In some cases (Kokka prospect, page 65) copper may be completely lacking, whereupon the amount of cobalt is also low. However, there may be several thousand ppm of copper, in which case cobalt is also regularly more abundant.

\section{The copper-cobalt-nickel triangular diagram}

The abundances of copper, nickel and cobalt and the nickel to cobalt ratios in various rocks were discussed above. A triangular diagram was constructed (Fig. 7) to study the interrelations of these elements. On the basis of this diagram, some general conclusions can be drawn.

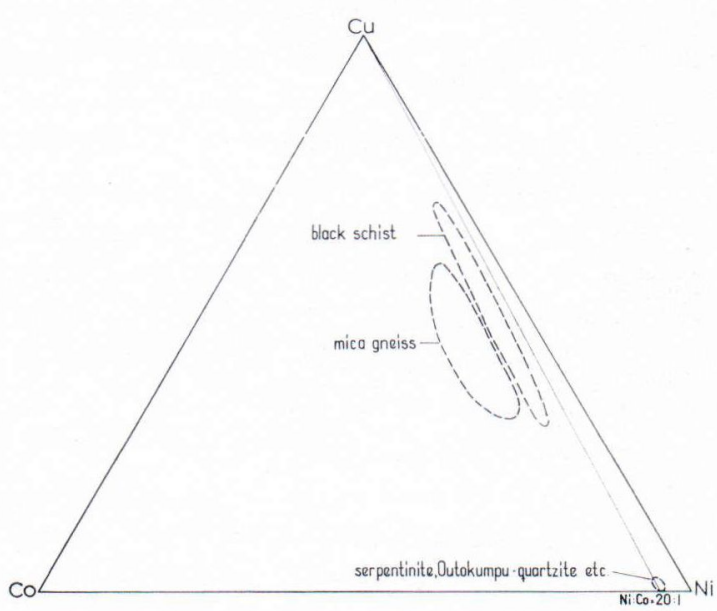

Fig. 7. $\mathrm{Cu}-\mathrm{Co}-\mathrm{Ni}$ triangular diagram. The normal concentration fields for the rocks of the Outokumpu type. 
In serpentinite and the quartzite-skarn-dolomite assemblage, nickel is predominant to such an extent that its relative amount rises to 94 96 per cent of the sum of the three metals. The relative amount of cobalt, $4-5$ per cent, is governed by an almost constant nickel to cobalt ratio. The percentage of copper is generally under 1 . Consequently, at the nickel apex of the triangle, practically all the points of the rock analyses are grouped within a small area.

The field within which the points of the black schist analyses fall is close to the $\mathrm{Ni}-\mathrm{Cu}$ side of the triangle (Ni : $\mathrm{Co}=6-10: 1)$. Due to the variation in the abundance of nickel and copper, the field extends as a narrow band towards the the $\mathrm{Ni}$ and $\mathrm{Cu}$ apexes.

As stated before, the nickel to cobalt ratio in mica gneiss is lower than that in black schist. Moreover, the abundances of nickel and copper in mica gneiss are approximately equal. Thus the mica gneiss field takes a position about half-way between the $\mathrm{Ni}$ and $\mathrm{Cu}$ apexes but further from the $\mathrm{Ni}-\mathrm{Cu}$ side than the black schist field.

The fields occupied by the copper ore points and those of nickel mineralisations are not marked on the triangular diagram. They will be discussed in more detail later. Due to the high concentration of copper, the field for the copper ores is near the $\mathrm{Cu}$ apex of the triangle, whereas the field of nickel mineralisations extends from the copper ore field to the $\mathrm{Ni}$ apex.

\section{Abundance of zinc in the rocks}

As stated before, the behaviour of zinc will not be treated in full in this study. However, some general observations concerning the abundance of zinc in various rock types will be given in brief below.

The serpentinites as well as the skarns and dolomites are poor in zinc. Usually their zinc tenor varies from 20 to $50 \mathrm{ppm}$. The quartzites differ from the above rocks due to the fact that they contain very small amounts of zinc, only 3 to $4 \mathrm{ppm}$. This does not mean, however, that the quartzites are completely free from zinc. In general zinc occurs as zincian chromite in quartzites with the consequence that zinc does not go easily into solution under the ordinary acid treatment which is used for dissolving sulphides.

Black schists are known to be relatively rich in zinc. Frequently the abundance varies from 500 to $2000 \mathrm{ppm}$.

The concentration of zinc in the mica gneisses is approximately the same as that of copper and nickel, i.e. under $100 \mathrm{ppm}$.

In general, the abundance of zinc in the copper-cobalt ores is rather high and of the same order of magnitude as that of copper. The concentration of zinc in the nickel mineralisations is low, usually 100 to $500 \mathrm{ppm}$.

\section{Deviations from the normal abundances and ratios}

In the foregoing, the background values of nickel, cobalt and copper in the rock association of the Outokumpu type were described. However, deviations from these values occur and one will be dealt with in the following.

The $\mathrm{Ni}-\mathrm{Co}$ and $\mathrm{Cu}$ - Co diagrams were drawn on the basis of all the analytical data pertinent to each rock assemblage. The diagrams are discussed in the same order as previously in connection with the general review.

\section{The nickel-cobalt diagrams}

The area of the serpentinite field in the diagram is small (Fig. 8). On account of the vast number of analyses the area appears as a black spot. However, there are some points which deviate considerably from the point of gravity of the bulk point distribution. Especially the points corresponding to $\mathrm{chlorite}$ and $\mathrm{t}$ a $1 \mathrm{c} \mathrm{s} \mathrm{chist} \mathrm{show} \mathrm{a} \mathrm{considerable} \mathrm{dispersion.}$ Nevertheless, no points are observed in the area characterised by the nickel to cobalt ratio noticeably exceeding that of $25: 1$. 


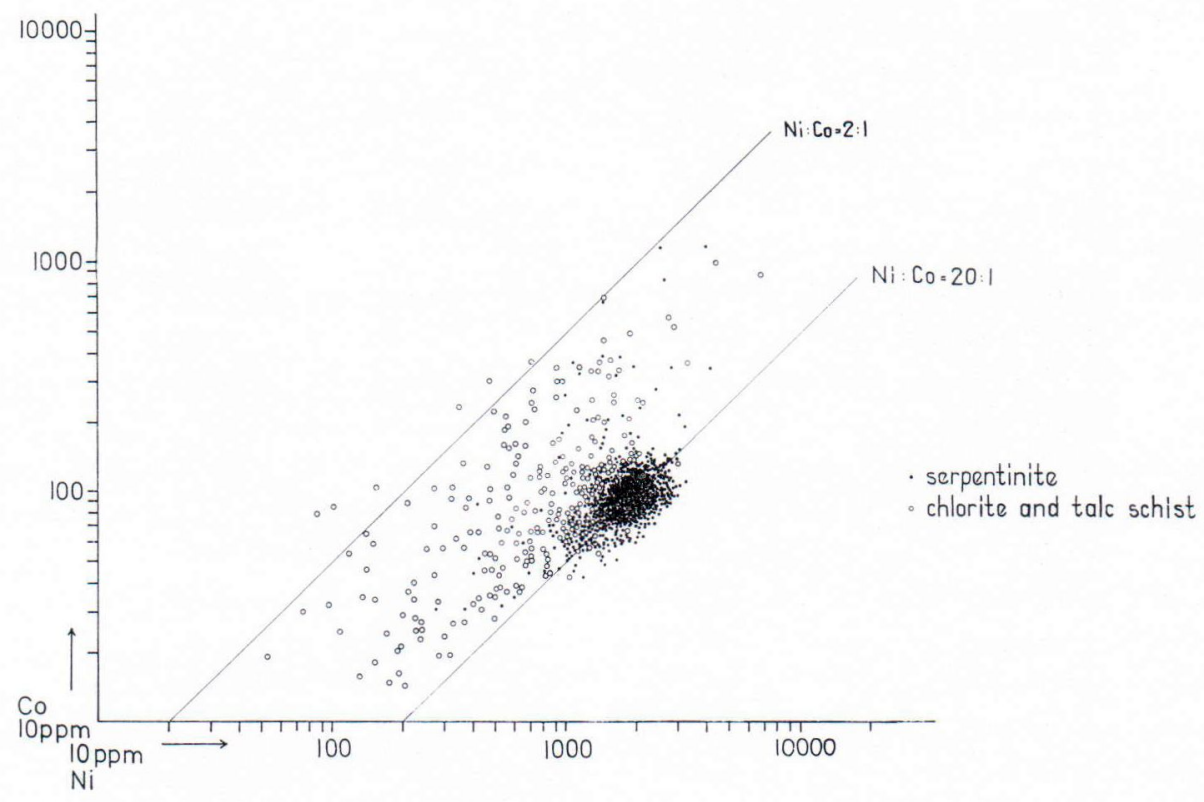

Fig. 8. Ni-Co diagram.

In some serpentinite points which lie further away from the field of background values, the abundance of nickel is similar to or slightly above normal (between 1000 and 4000 ppm), whereas the abundance of cobalt shows considerably higher values which fluctuate between the average concentration (100 ppm) and $1000 \mathrm{ppm}$. The numerical value of the nickel to cobalt ratio decreases with the increase in the cobalt tenor. In some cases, the ratio approaches $2: 1$.

In general, the chlorite and talc schists contain less nickel and cobalt than the serpentinites. In spite of that the fluctuation in the abundances may be considerable as is indicated by the scattered points in the diagram. A part of the samples are rich in nickel and/or cobalt. Most of them are chlorite schists but a few talc schist samples are also included. The nickel to cobalt ratio decreases due to the fact that the abundance of cobalt increases at a higher rate than that of nickel. The numerical values of the nickel to cobalt ratio vary from the normal value down to $2: 1$ or even lower.
The points relatively rich in cobalt with the nickel to cobalt ratio noticeably below average represent anomalous types, which include serpentinites, chlorite and talc schists whose nickel to cobalt ratio is less than $15: 1$.

It was confirmed that there is a correlation between the local increase in the abundance of cobalt and the presence of the copper-cobalt ores or mineralisations.

The major part of the points in Fig. 9 represents quartzites and skarn-bearing quartzites. Also s ka rns are abundant whereas the number of dolo mite points is low.

The diagram also includes the copper-cobalt ores associated with the above rocks. Most often the ores occur in quartzite. In this study a rock with a copper tenor of 0.9 per cent of higher is considered as an ore.

In most of the quartzite, skarn and dolomite samples the abundances of nickel and cobalt are normal. There are some exceptions to this rule but they are rather few compared with the total number of samples. 


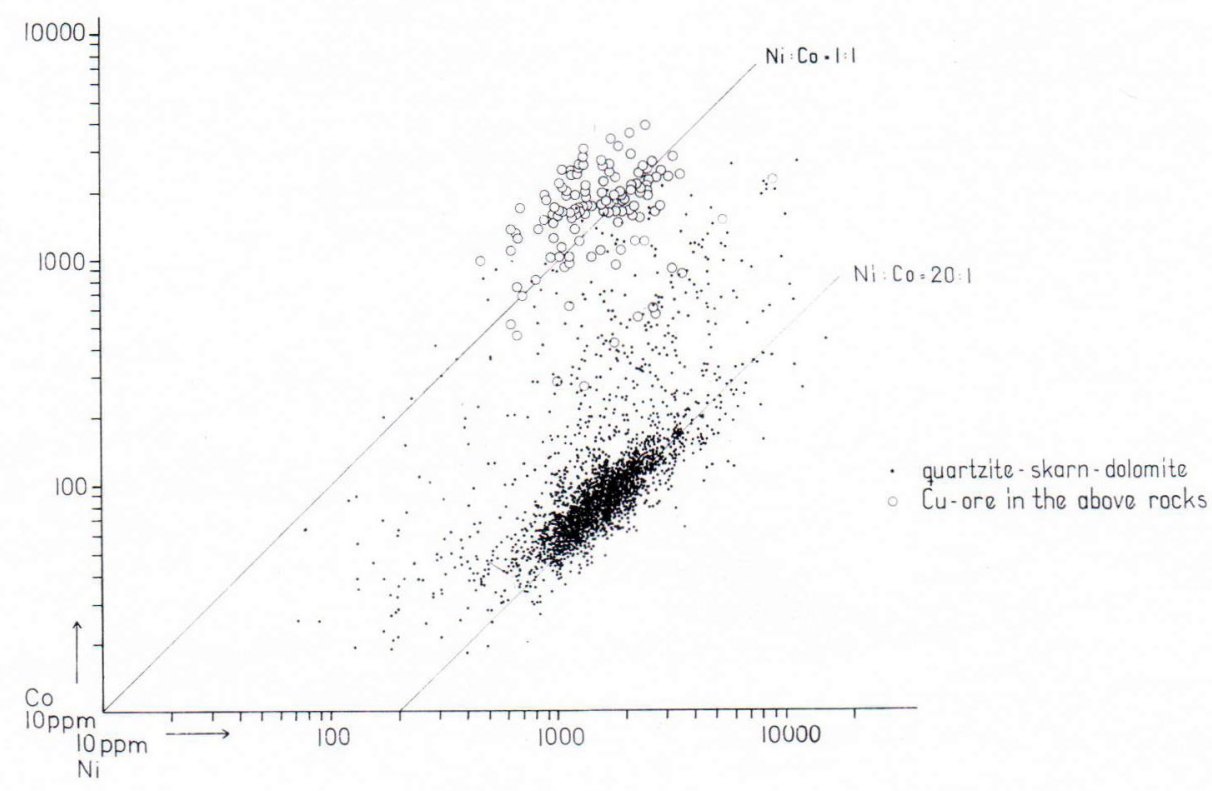

Fig. 9. Ni-Co diagram.

The most important and largest field of points representing anomalous values is on the diagram between the quartzite and ore fields (Fig. 9). Various kinds of gradational types of quartzites, skarns and dolomites are encountered in which the abundance of cobalt increases and the nickel to cobalt ratio decreases towards the copper-cobalt ores. In the latter, the abundance of cobalt usually exceeds that of nickel. Should the cobalt tenor rise up to approximately $1000 \mathrm{ppm}$, then the copper content is fairly often of ore grade.

The anomalous points, representing quartziteskarn-dolomite assemblages with a nickel to cobalt ratio less than $15: 1$, are characterised by slightly higher nickel percentages than the points of the normal quartzite-skarn-dolomite assemblages and the copper ore. In extreme cases the abundance of nickel exceeds 3000 ppm giving rise to marginal ore grades.

Anomalous quartzite-skarn-dolomites abnormally rich in cobalt, have been encountered in areas where copper-cobalt ores or mineralisations occur. These anomalies are not always directly associated with the ores but they may occur as separate zones in serpentinite-quartzite assemblages. In general they are richer than normal in sulphides. The fact that they are also frequently slightly richer in nickel, sometimes even to a considerable extent, can be attributed to the migration of the sulphides of the copper-cobalt ores in the nickel-bearing serpentinite-quartzite assemblages from which they have acquired extra nickel.

The other type of nickel mineralisations has been observed to have formed in skarns at the contacts of black schists rich in sulphides as described by A. Huhma on page 65 . However, the nickel to cobalt ratio is normal or slightly higher than that. The diagram in Fig. 9 contains points representing also these cases.

In this context it is advisable to return to the general nickel to cobalt ratios of the rocks presented in a former chapter of this paper. According to the diagrams (Figs. 8 and 9), the nickel to cobalt ratio in the serpentinite-quartzite assemblages varies between $15: 1$ and $25: 1$, with an average of $20: 1$. This finding was obtained from the analytical data of several prospects. Some 


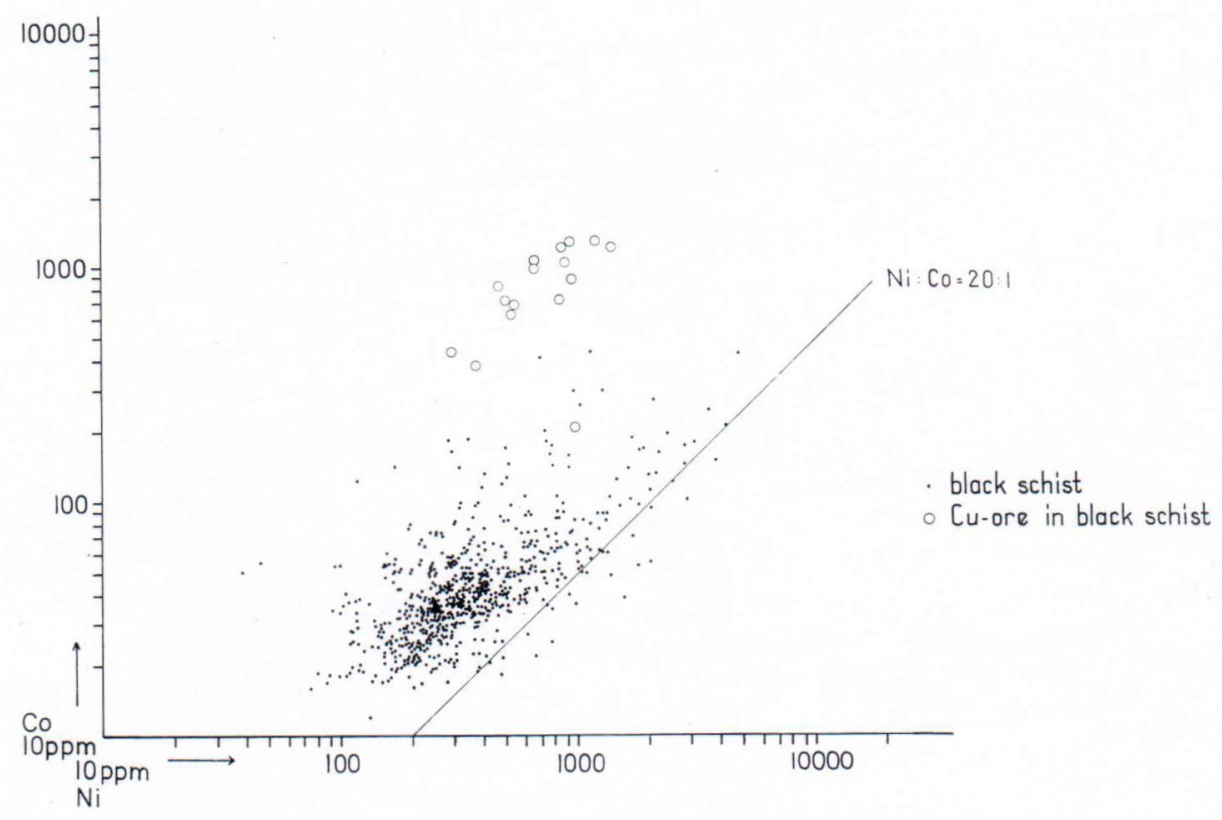

Fig. 10. Ni-Co diagram.

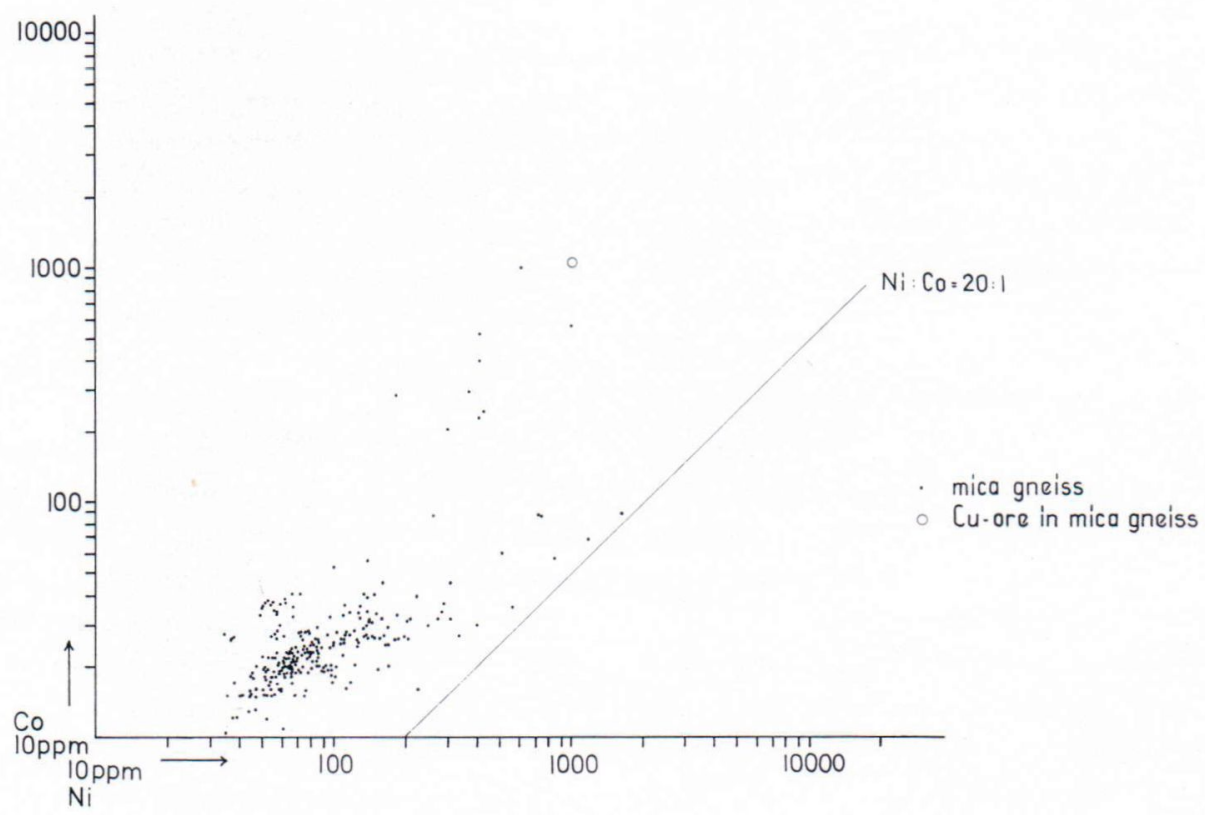

Fig. 11. Ni-Co diagram.

of these prospects contain copper-cobalt ores. Whenever the ore or $\mathrm{Cu}-\mathrm{Co}$ mineralisation is lacking in serpentinite-quartzite assemblages the nickel to cobalt ratio is between $20: 1$ and $25: 1$ or even higher. This must be taken as the primary nickel to cobalt ratio in the rocks. When a copper-cobalt ore is present it reduces the average nickel to cobalt ratio in the rocks. 
In the Outokumpu zone, b l a c k s c h is t s (Fig. 10) relatively rich in cobalt form a group of their own. The black schist becomes enriched in cobalt whenever sulphides of the copper-cobalt ores occur in them. Occasionally it has been observed that the copper-cobalt ore extends into black schist, as is indicated by the diagram.

The mica gneisses serve only as a frame in studies concerning the Outokumpu zone and consequently, the number of analysed mica gneiss samples is low. The diagram (Fig. 11) contains some points with a high cobalt tenor outside the concentration field proper. They reflect the influence of the copper-cobalt ores, and in some places the mica gneiss serves as a host rock for the ore.

On the basis of the above descriptions it might be concluded that the copper-cobalt ores of the Outokumpu type occur only in serpentinitequartzite zones. Since this is not compatible with the facts, a case dissimilar from the forementioned is described below (Riihilahti, Fig. 12).

The Riihilahti ore occurs in a mica gneiss area. No serpentinite-quartzites have been encountered and black schists are rare. The mica gneiss has amphibolitic (calcareous) intercalates.
At the prospect mica gneisses and amphibolites grade into garnet (almandine)-cummingtonite gneisses and cummingtonite-amphibolites, respectively. Moreover, diopside-amphibole-plagioclase rocks are met with as well as smaller amounts of olivine-spinel-amphibole rocks and many kinds of variants between these. Copper ore has been encountered in all of these rocks including mica gneiss. However, the compact portions are restricted mainly to diopside-plagioclase skarns.

The analytical data from a few drilling profiles containing all the above rocks are plotted on the diagram (Fig. 12).

The ore has produced a rather extensive anomlay in its environment. Parallel to it, alteration phenomena can be observed in the rocks.

The anomaly is manifested by an increase in the cobalt tenor, whereas the abundance of nickel remains nearly constant. Not until the abundance of cobalt reaches a level approximately 5 times that of nickel does the nickel tenor start to increase sympathetically with that of cobalt. This takes place in such a way that nickel to cobalt ratio remains constant. The $\mathrm{Ni}: \mathrm{C}_{0}=1: 5$

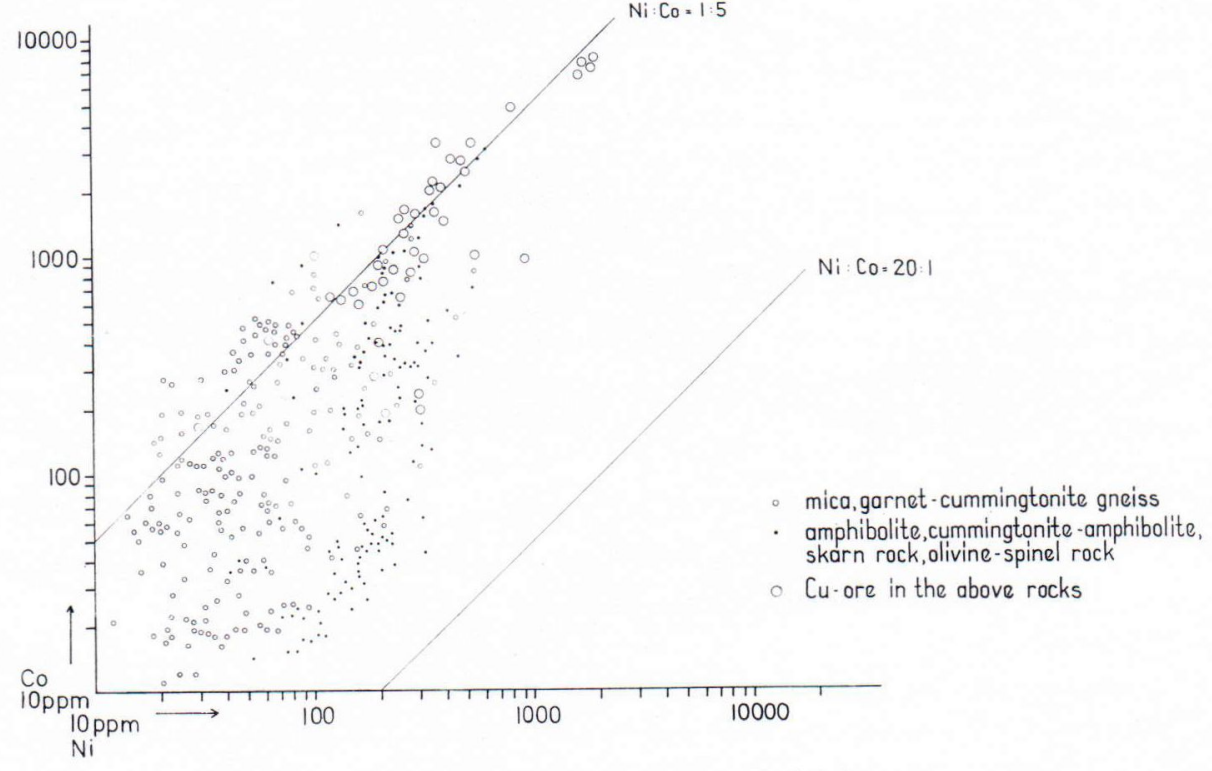

Fig. 12. Ni-Co diagram. Riihilahti. 
points with the highest cobalt and nickel tenors represent an almost compact pyrrhotite-chalcopyrite-cobalt pentlandite ore.

Some samples were also analysed for sulphur, and it was observed that in this ore the sulphur to cobalt ratio, $40: 1$, is almost constant.

The abundances of nickel and cobalt were determined in some mafic silicates by means of an electron probe microanalyser. The concentrations of nickel and cobalt (as well as copper) in the silicates were confirmed to be proportional to those in the sulphides. Thus, e.g. olivine contains more cobalt than nickel showing a stricking dissimilarity to the normal nickel-predominant olivines in peridotites.

Examination of the diagrams (Figs. 8-12) reveals that the anomalous zones, while retaining the normal nickel tenor of each rock, form zones rising upwards. Thus the anomalies in the serpentinite-quartzite assemblages are the richest in nickel (more than $1000 \mathrm{ppm}$ ). The anomalies in the black schists vary from 400 to $1000 \mathrm{ppm} \mathrm{Ni}$, in the amphibolites from 150 to $350 \mathrm{ppm} \mathrm{Ni}$, while the anomaly field of the mica gneiss, which is the poorest in nickel, lies between 20 and 100 ppm Ni.

The same holds true also to the nickel contents of the copper-cobalt ores. The ore in a quartzite-skarn-assemblage (Fig. 9) is somewhat richer in nickel than the ores in black schist, mica gneiss or amphibolite (Figs. 10-12). The cobalt contents of the ores vary usually between 1000 to $3000 \mathrm{ppm}$ even though in some samples the concentrations may deviate considerably from the average.

In the area investigated, nickel and cobalt are mainly incorporated in one mineral only, pentlandite, which in the copper ores occurs as cobalt pentlandite. The mineral is always in close association with pyrrhotite. Unlike pyrrhotite, chalcopyrite, as a more mobile sulphide, has been concentrated occasionally beyond the borders of the ore proper, in which case the amount of pyrrhotite and pentlandite has remained low. This explains the cobalt-poor ore points on the diagrams. The cobalt-rich ore points represent compact ores rich in sulphides.

Occasionally copper ore may be rich in nickel (3 000 to $9000 \mathrm{ppm}$ ) without having any remarkable cobalt tenor. The nickel to cobalt ratio varies in different ores but also locally within a single orebody. The nickel to cobalt ratios in the ores will be discussed in more detail later in this paper.

The changes the copper-cobalt ores produce in the normal concentrations of the rocks are manifested as an increase in the cobalt tenor on account of which the nickel to cobalt ratio gradually decreases parallel to the increase in the influence of the ores. The ores represent the rocks richest in cobalt.

As mentioned above pentlandite is the principal carrier of nickel and cobalt. A number of pentlandites from various rocks (including ores and anomalous rocks) were analysed by electron microprobe (Table I).

\section{TABLE I}

Chemical composition of pentlandites from the Vuonos deposit. Electron microprobe analyses. $25 \mathrm{kV}, 0.05 \mu \mathrm{A}$, LiF and mica crystals.

\begin{tabular}{|c|c|c|c|c|c|}
\hline Rock type & $\mathrm{Ni}$ & Co & $\mathrm{Fe}$ & S & Total \\
\hline skarn ......... & 32.62 & 1.04 & 30.28 & 35.95 & 99.89 \\
\hline serpentinite . . . . & 35.36 & 1.11 & 28.65 & 35.36 & 101.67 \\
\hline chlorite schist .. & 34.59 & 1.57 & 27.65 & 35.80 & 99.61 \\
\hline skarn $\ldots \ldots \ldots$ & 33.23 & 1.76 & 27.78 & 35.24 & 98.01 \\
\hline quartzite $\ldots \ldots$. & 35.05 & 2.01 & 26.28 & 35.51 & 98.85 \\
\hline dolomite...$\ldots$. & 30.94 & 3.88 & 28.12 & 35.34 & 98.28 \\
\hline $\operatorname{skarn} \ldots \ldots \ldots$ & 33.47 & 4.82 & 25.97 & 35.99 & 100.25 \\
\hline serpentinite $\ldots$. & 28.51 & 6.27 & 28.55 & 35.55 & 98.88 \\
\hline chlorite schist .. & 31.70 & 7.48 & 24.82 & 35.81 & 99.81 \\
\hline quartzite $\ldots \ldots \ldots$ & 30.72 & 8.31 & 24.76 & 35.70 & 99.49 \\
\hline serpentinite .... & 29.65 & 9.16 & 25.14 & 35.80 & 99.75 \\
\hline skarn $\ldots \ldots \ldots$ & 30.40 & 9.28 & 24.10 & 35.67 & 99.45 \\
\hline serpentinite $\ldots \ldots$ & 27.04 & 11.46 & 24.97 & 35.52 & 98.99 \\
\hline chlorite schist .. & 26.65 & 12.98 & 23.62 & 35.35 & 98.60 \\
\hline quartzite $\ldots \ldots \ldots$ & 21.85 & 19.95 & 22.51 & 35.90 & 100.21 \\
\hline $\begin{array}{l}\text { Cu-dissemina- } \\
\left.\operatorname{tion}^{1}\right) \ldots \ldots \ldots\end{array}$ & 18.84 & 25.22 & 19.31 & 35.28 & 98.65 \\
\hline $\mathrm{Cu}$-ore $\left.{ }^{1}\right) \ldots \ldots$ & 19.24 & 29.81 & 14.87 & 35.44 & 99.36 \\
\hline $\mathrm{Cu}$-ore $\left.{ }^{1}\right) \ldots \ldots$ & 15.92 & 36.30 & 11.34 & 35.14 & 98.70 \\
\hline
\end{tabular}

1) in quartzite

It was established that the nickel to cobalt ratio in the rocks is reflected in the composition of the pentlandite. Thus the pentlandites in serpentinites and quartzite-skarn-dolomite assemblages 
are normal nickel pentlandites. Parallel to the increase in cobalt in the rock, the abundance of cobalt in pentlandite also increases and reaches the highest values in the copper-cobalt ores. Consequently, the nickel to cobalt ratio is the same in the pentlandite and the host rock.

Similar behaviour of cobalt and nickel can be seen in the data given by Kouvo and his colleagues concerning the cobalt pentlandite (Kouvo et al. 1959). According to them, the Riihilahti pentlandite richest in cobalt contains 49.33 per cent $\mathrm{Co}$ and 9.06 per cent $\mathrm{Ni}$ with a nickel to cobalt ratio of $1: 5.4$. This is the same as the ratio in the ore (Fig. 12). A similar tendency can also be observed in the abundances of nickel and cobalt in pyrrhotite. The pyrrhotite in the ore contains more cobalt than nickel whereas the pyrrhotite in the serpentinite-quartzite assemblage is nickel-predominant.

\section{The copper-cobalt diagrams}

The abundance of copper in serpen$\mathrm{t}$ i $\mathrm{n} \mathrm{it} \mathrm{e} \mathrm{s} \mathrm{is} \mathrm{low} \mathrm{and} \mathrm{even} \mathrm{a} \mathrm{content} \mathrm{of} 100 \mathrm{ppm}$ can be regarded as exceptional. However, there are such points among those plotted on the diagram (Fig. 13), although fairly unfrequently.
Occasionally the copper tenor reaches values as high as $2000 \mathrm{ppm}$. Wheri the copper content is low, less than $100 \mathrm{ppm}$, the distribution of the points on the diagram is horizontal. With the increase in the abundance of copper, the distribution tends to rise. This is accompanied by an increase in the cobalt content.

The above holds true to a great extent in chlorite and talc schists. The only difference as compared with serpentinites is that their cobalt and nickel tenors are lower. Consequently the points lie below the serpentinite field. The highest copper concentrations in chlorite schists are of the same order of magnitude as those in the serpentinites (2000 ppm). In these cases both rocks contain about 1000 ppm Co.

Anomalous copper concentrations $(\mathrm{Cu}>100$ ppm) are encountered in serpentinites and chlorite schists as well as sometimes in talc schists in the areas in which copper-cobalt ores occur.

The diagram of the qua $\mathrm{rtz}$ i t e - s k a r n d ol o mit e assemblage (Fig. 14) bears a very close resemblance to that of the serpentinites. If the copper content is within background range, i.e. below $100 \mathrm{ppm}$ the distribution of the points is horizontal. Whenever the copper content exeeds $100 \mathrm{ppm}$, the abundances of copper and

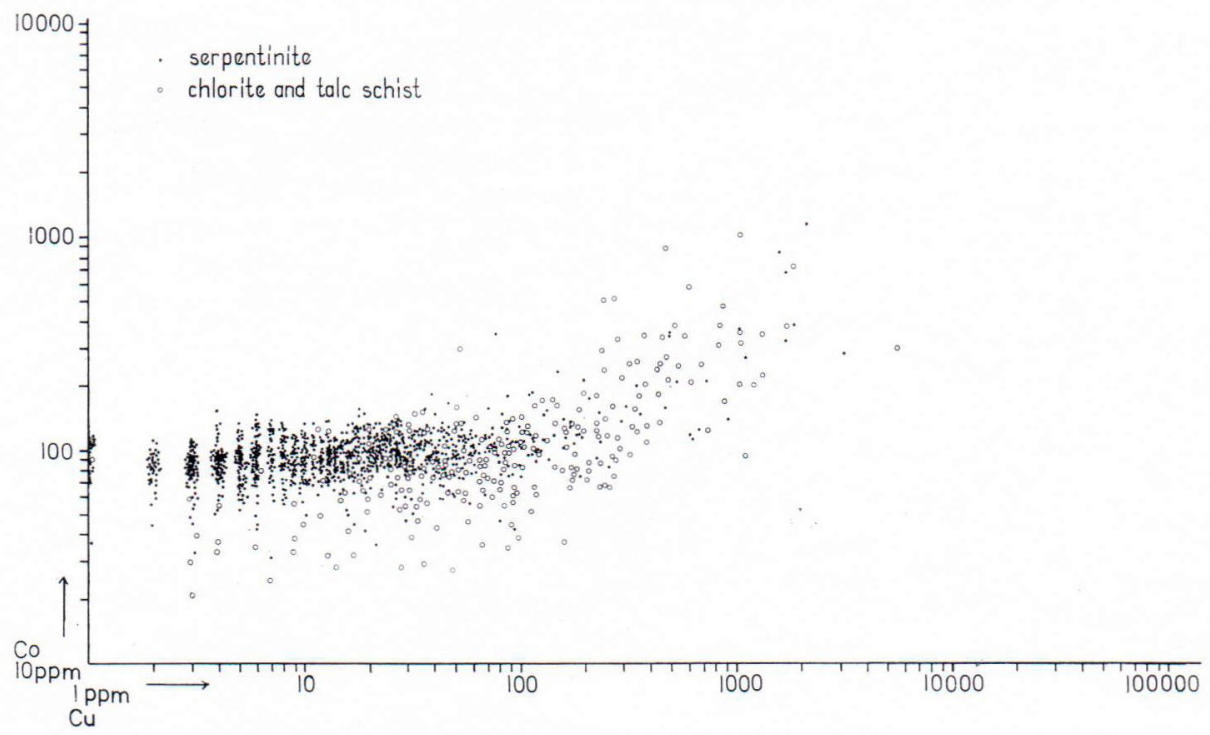

Fig. 13. $\mathrm{Cu}-\mathrm{Co}$ diagram. 


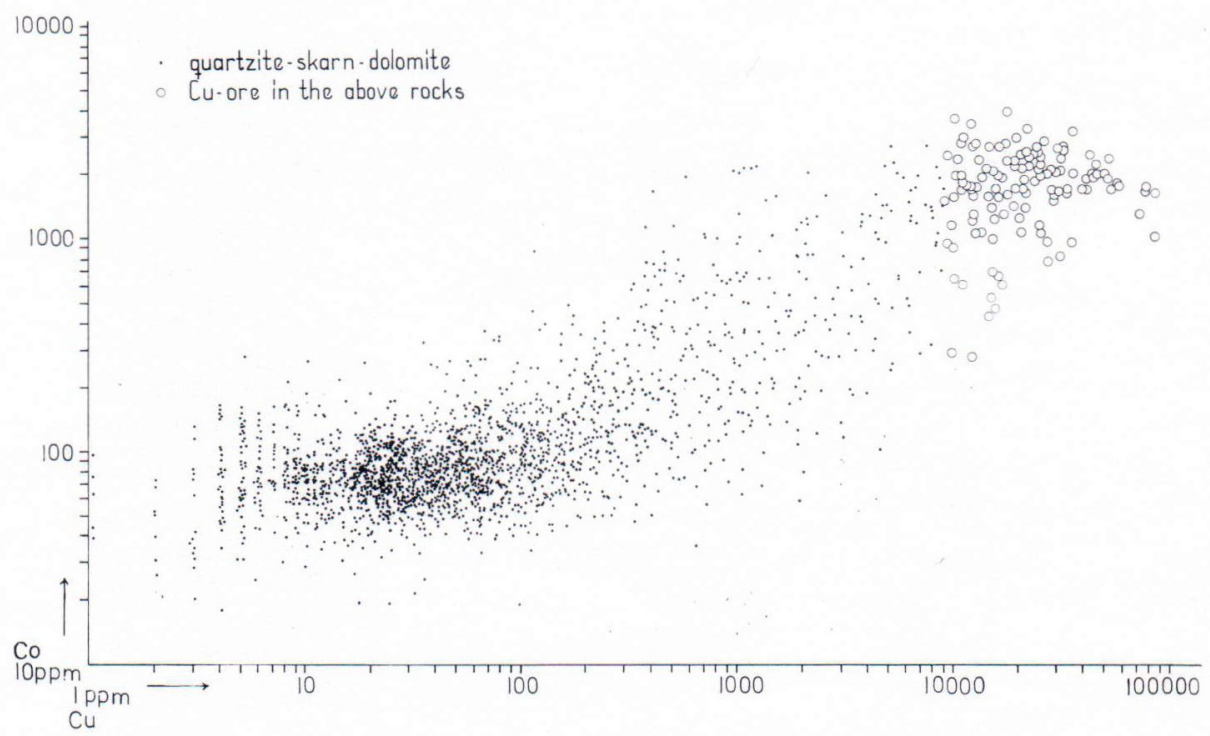

Fig. 14. $\mathrm{Cu}-\mathrm{Co}$ diagram.

cobalt correlate with each other. The copper tenor increases sympathetically with that of cobalt and finally the area occupied by the ore points is reached.

The zone of the anomalous points ( $\mathrm{Cu}$ between 100 and $9000 \mathrm{ppm}$ ) is rather wide and the copper to cobalt ratio varies considerably. This is due to the fact, as stated before, that chalcopyrite and pentlandite have different modes of occurence.

Should the sulphides of the copper-cobalt ores produce anomalies in the black schist s, the high copper content is accompanied by a high cobalt content. The diagram in Fig. 15

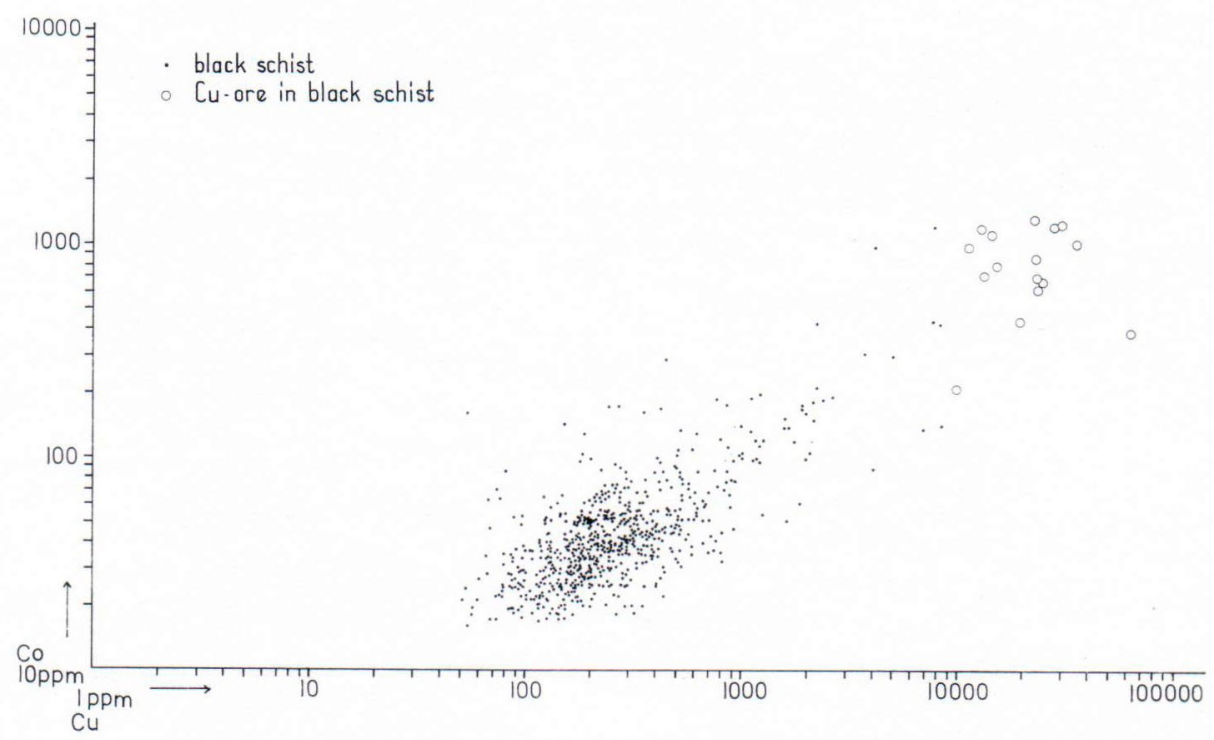

Fig. 15. $\mathrm{Cu}-\mathrm{Co}$ diagram. 


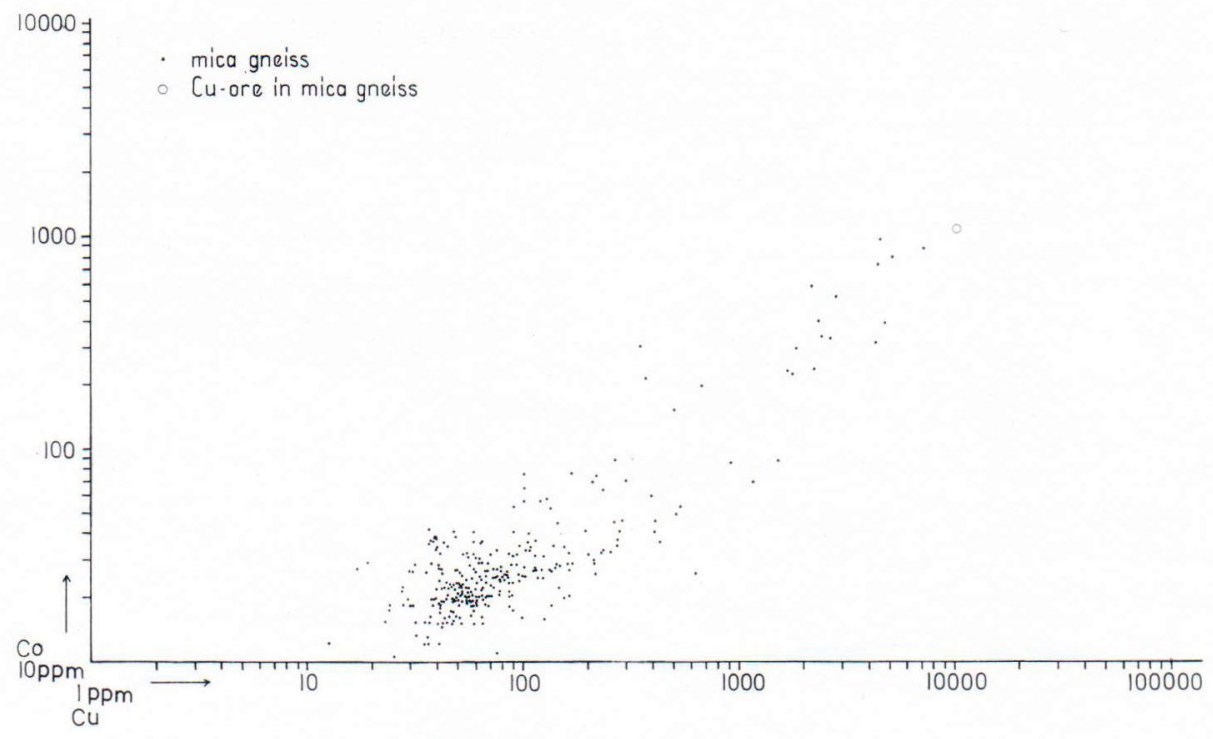

Fig. 16. $\mathrm{Cu}-\mathrm{Co}$ diagram.

shows such a belt of scattered points running from the black schist field towards the coppercobalt ore field. In some places ore occur in black schist.

Some $\mathrm{mica} g \mathrm{neiss}$ es are rather rich in cobalt and contain more copper than black schists. These points on the diagram (Fig. 16) extend, as on the previous diagrams, towards the copper-cobalt ore field. Occasionally the abundance of copper in mica gneiss reaches that in the ore.

The copper-cobalt diagram in Fig. 17 depicts the Riihilahti case, in which the ore is embedded in a mica gneiss-amphibolite environment. The

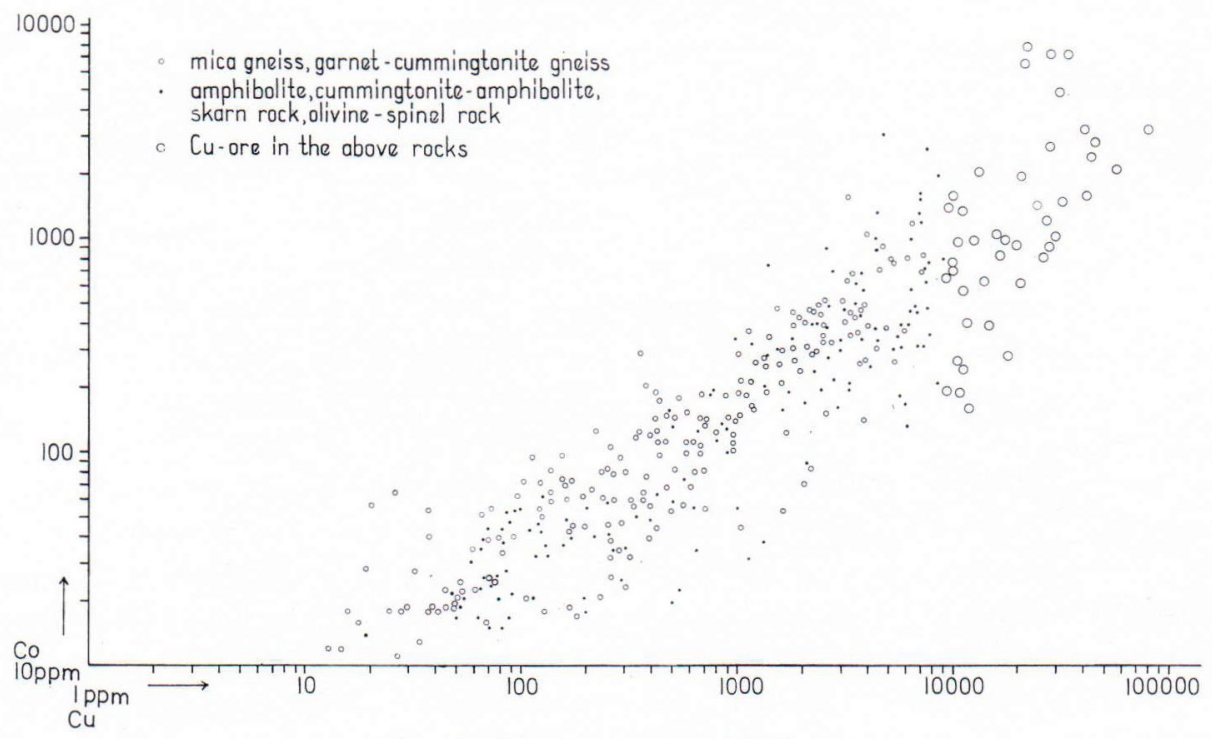

Fig. 17. Cu-Co diagram. Riihilahti. 
points extend from the mica gneiss and amphibolite fields in the lower part of the diagram up to the field of ore with the copper and cobalt tenors increasing.

Comparison of the above copper-cobalt diagrams with each other reveals that the anomalous belts (Fig. 13-17) extend from the fields of each rock towards the field of the copper-cobalt ores. The uppermost anomaly belt, that of serpentinites and the quartzite-skarn dolomite assemblage, beings in the area in which the abundances of cobalt and copper are approximately $100 \mathrm{ppm}$. The anomalies in the black schists begin when the concentration of copper reaches about 350 $\mathrm{ppm}$ and that of cobalt $50 \mathrm{ppm}$. The anomaly threshold is even lower in mica gneisses and amphibolites. All the anomaly belts tend towards the field of the copper-cobalt ores.

Some of the orebodies have sharp contacts. Their influence on the environment comes to an end for a short distance and no anomalous areas are observable. However, separate anomalous zones may exist further from the ore. In places the borders of the ore are less sharp and the influence of the ore on the environment extends further, dying out as it gradually draws away from the ore. The anomalous area then lies in the immediate vicinity of the ore.

The former holds true e.g. when ore occurs in quartzite (Vuonos). The latter is characteristic of ores of the skarn-dolomite assemblage (Hietajärvi) or of mica gneiss (Riihilahti).

The abundance of copper in c o p per - c ob a $1 \mathrm{t}$ or e samples varies between 0.9 per cent and 8 per cent and that of cobalt between 0.02 per cent and 0.8 per cent. The copper to cobalt ratio shows considerable fluctuation, as illustrated by the diagrams (Figs. 14-17). This can be attributed to the difference in the mode of occurrence of chalcopyrite and cobalt pentlandite, as stated before. The lowest cobalt concentrations are met with at the periphery of the ore in places where chalcopyrite has migrated for some distance from the ore proper. The cobalt-rich points represent compact ore types.

\section{The nickel to cobalt ratio in some copper- cobalt ores}

In the foregoing, the changes caused by the copper-cobalt ores of the Outokumpu type to the normal concentrations of nickel, cobalt and copper in the country rocks were discussed.

In the following, attention is focused on the influence of the environment on the composition of the ores with special emphasis on the nickel to cobalt ratio. The subject is illustrated by copper-cobalt-nickel triangular diagrams.

\section{Sola}

A small copper mineralisation in association with large serpentinite-quartzite bodies occurs at Sola embedded in skarn-bearing quartzites. On the triangular diagram (Fig. 18), the belt of the anomalous points extends from the serpentinite-quartzite field near the $\mathrm{Ni}$ apex towards the $\mathrm{Cu}$ apex, the copper ore. The anomalous rocks are quartzites, skarns, chlorite schists and their variants. With the increase in the copper content the nickel to cobalt ratio becomes increasingly more cobalt-predominant to such an extent that in the ore it is on an average $5: 1$. Thus, the distribution of the points is restricted within an area close to the $\mathrm{Ni}-\mathrm{Cu}$ side in the triangle.

\section{Hietajärvi}

A zone of skarns and dolomites of the Outokumpu type, modest in dimensions, occurs in an environment of mica gneisses and black schists. The skarns and dolomites are represented on the triangular diagram (Fig. 19) by a few points close to the Ni apex. A small copper ore is associated with the skarn-dolomite assemblage. There are two orebodies one of which occurs in larger skarn-dolomites than the other. Some anomalies have been encountered in the environment of the ore in skarn-dolomites, graphite skarns and graphite gneisses as well as in mica gneisses. It is characteristic of the anomalies that the nickel to cobalt ratio becomes cobalt-predominant with 


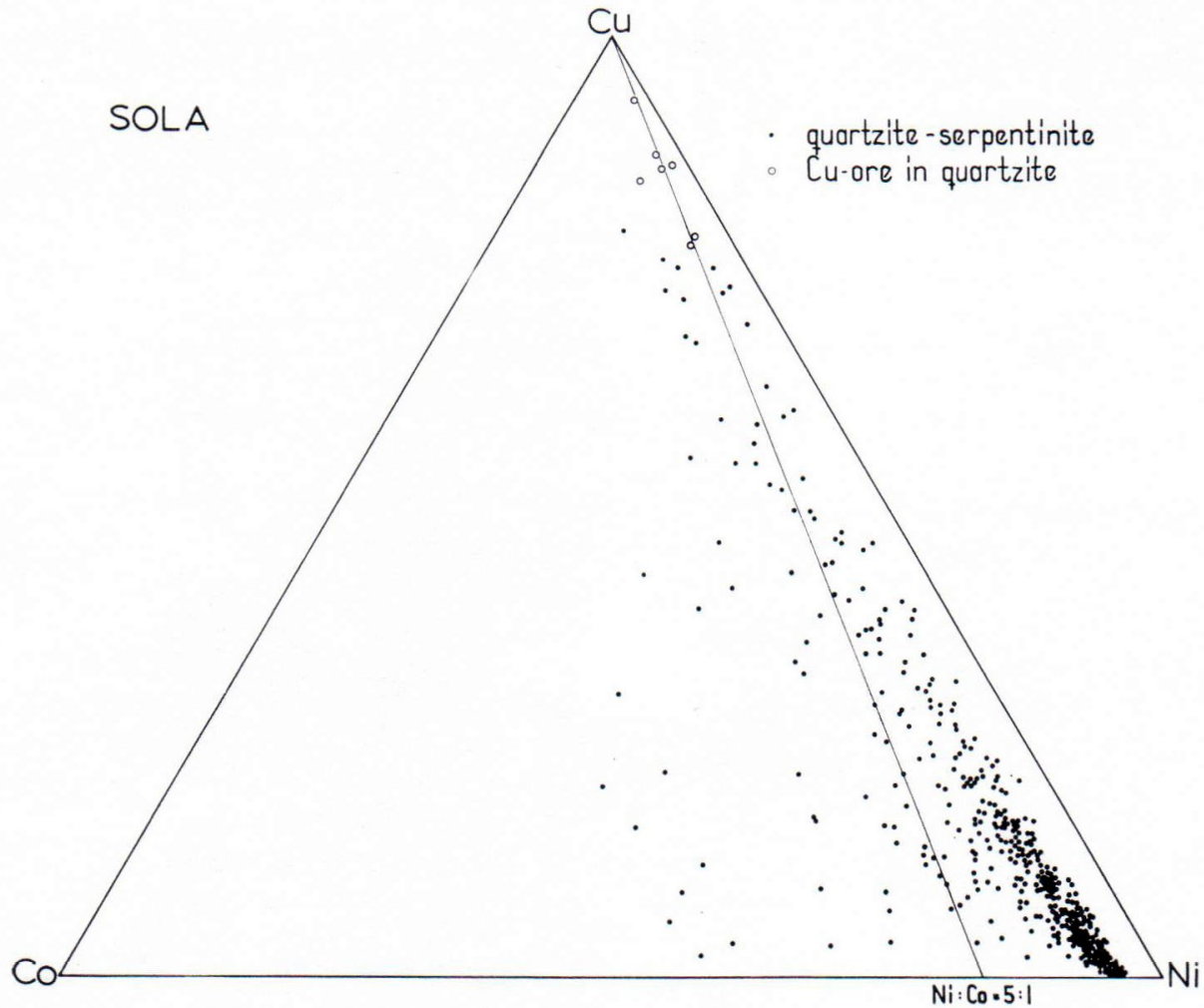

Fig. 18. $\mathrm{Cu}-\mathrm{Co}-\mathrm{Ni}$ triangular diagram. Sola.

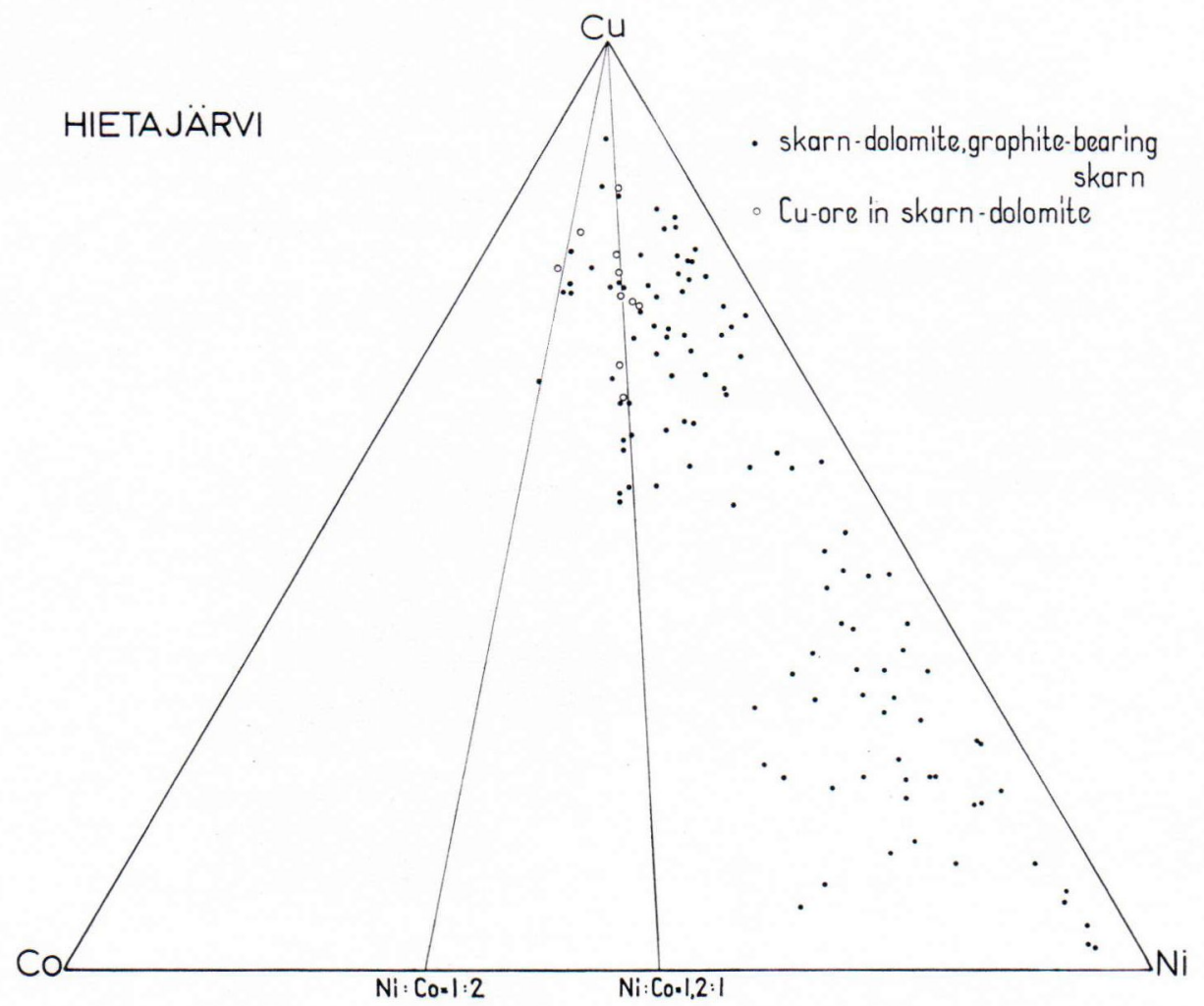

Fig. 19. $\mathrm{Cu}-\mathrm{Co}-\mathrm{Ni}$ triangular diagram. Hietajärvi. 


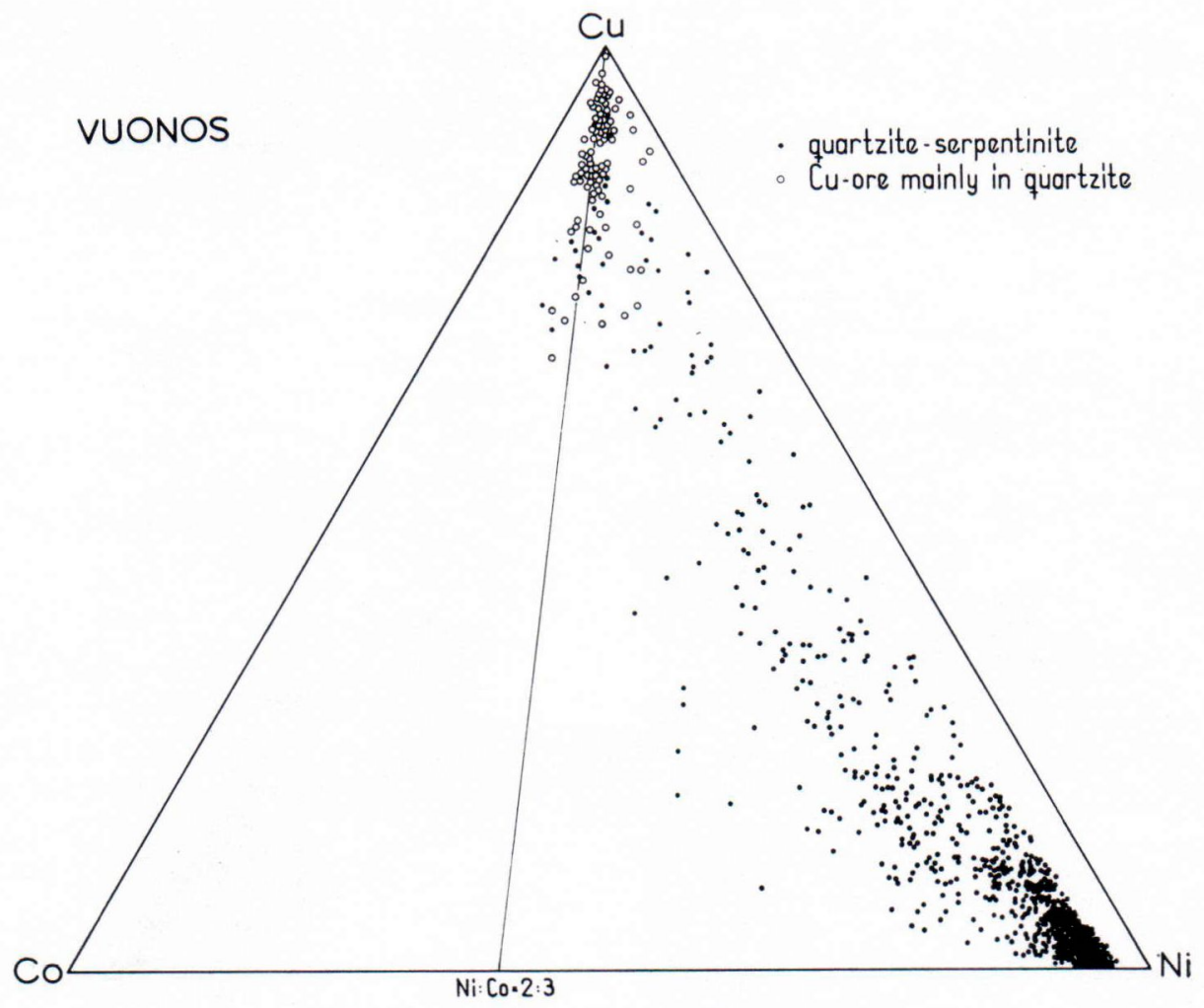

Fig. 20. $\mathrm{Cu}-\mathrm{Co}-\mathrm{Ni}$ triangular diagram. Vuonos.

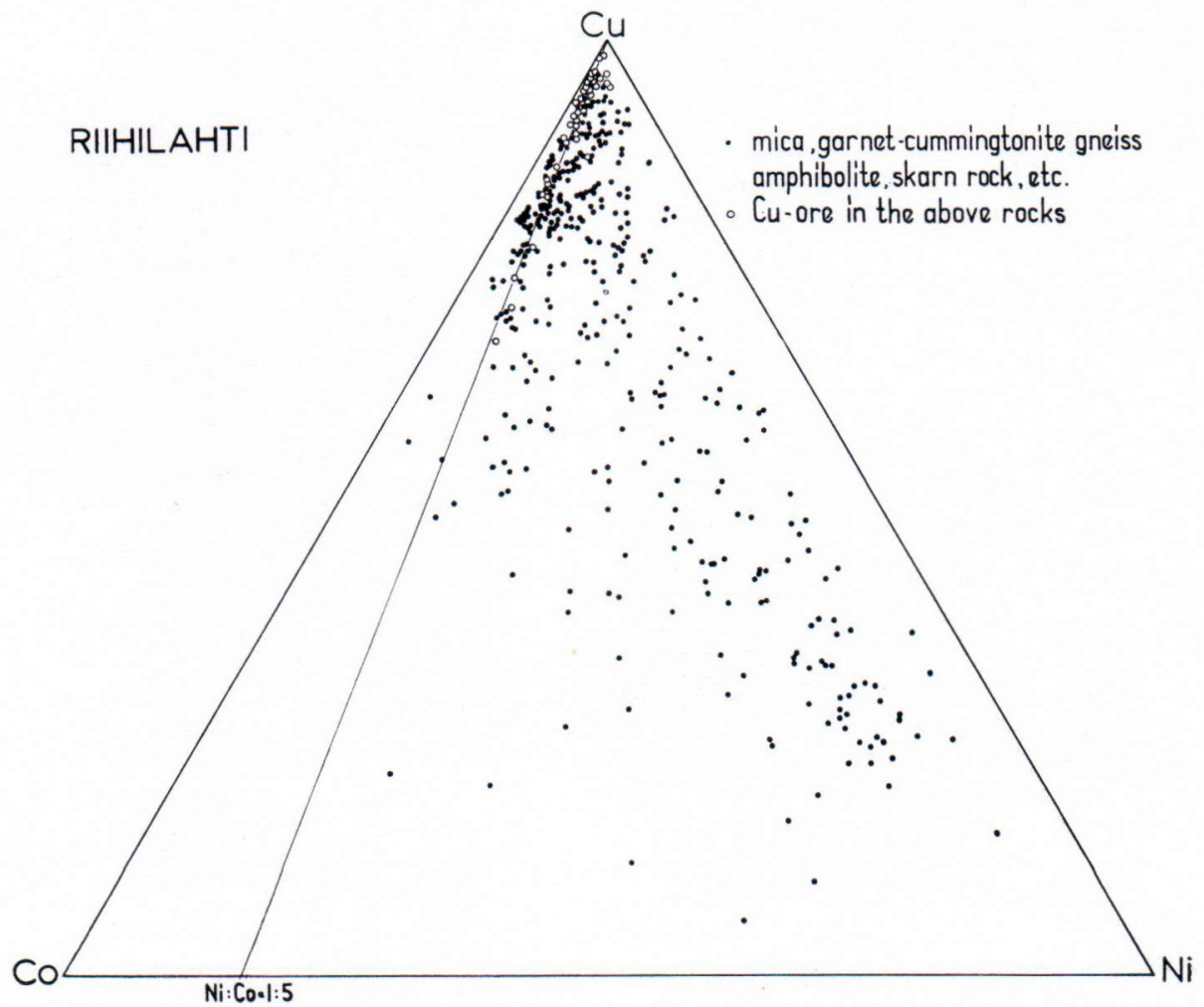

Fig. 21. $\mathrm{Cu}-\mathrm{Co}-\mathrm{Ni}$ triangular diagram. Riihilahti. 
the increasing copper content. In the larger ore body the nickel to cobalt ratio is $1.2: 1$ whereas in the minor lens, where the amount of nickel skarns and dolomites is small, the ratio is $1: 2$.

\section{Vuonos}

At Vuonos the ore is associated with large serpentinite and quartzite bodies. The dimensions of the ore body are considerable. Most of the serpentinites and skarns have normal $\mathrm{Ni}-\mathrm{Co}-$ $\mathrm{Cu}$ values. This is illustrated by numerous points close to the Ni apex on the triangular diagram (Fig. 20). Many anomalous points including those of nickel mineralisation also exist, the rocks being quartzite-skarn-dolomites, chlorite schists and to some extent serpentinites as well as all possible variants between them. Towards the copper apex the nickel to cobalt ratio of the anomalous points decreases until it reaches an average value of $2: 3$ in the ore. There are some exceptions to this rule depending on the host rock which is usually quartzite. Occasionally it is skarn-bearing or black schist predominant, in which case the ore is richer in nickel compared with the abundance of cobalt.

\section{Riibilabti}

The Riihilahti ore is situated exceptionally in the mica gneiss area (garnet-cummingtonite rocks etc.). Serpentinites and quartzites are lacking and consequently the $\mathrm{Ni}$ apex on the triangular diagram (See Fig. 21) is free from points.

The points closest to the $\mathrm{Ni}$ apex represent amphibolites, slightly above them there is a field of normal mica gneisses (Fig. 7).
As stated before (Figs. 12 and 17), the influence of the copper-cobalt ore extends over all the rocks in the area. Consequently, a continuous increase in the abundance of copper and cobalt can be observed starting with the mica gneisses and amphibolites and continuing towards the ore.

In the ore, in which the cobalt content is higher than in any other rock included in this study, the nickel to cobalt ratio is $1: 5$ or, occasionally, even less than that.

The above examples suggest, that the environment has an effect on the nickel to cobalt ratio in the copper-cobalt ores of the Outokumpu type. The larger are the serpentinite-quartzites and the smaller is the ore, the greater is the influence of the environment on the nickel to cobalt ratio in the ore. If the ore is large or the nickel-bearing environment is lacking, the ores are clearly cobalt-predominant. The question may be raised as to whether the Riihilahti case represents the primary nickel to cobalt ratio in the copper-cobalt ores of the Outokumpu type or whether the primary ratio is even more cobaltpredominant.

\section{The Outokumpu ore and other copper-cobalt ores}

The Outokumpu ore and its immediate environment has not been investigated in detail for this study. However, in the following a short survey is given followed by comparisons between the Outokumpu ore and the other deposits described in the paper.

The analytical data available concerning the Outokumpu ore (Peltola, 1967) come from the

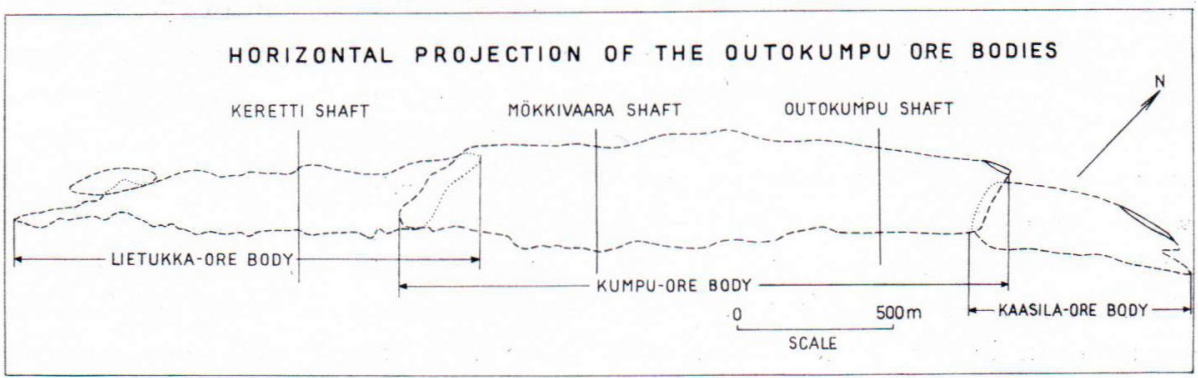

Fig. 22. Outokumpu ore deposit. 


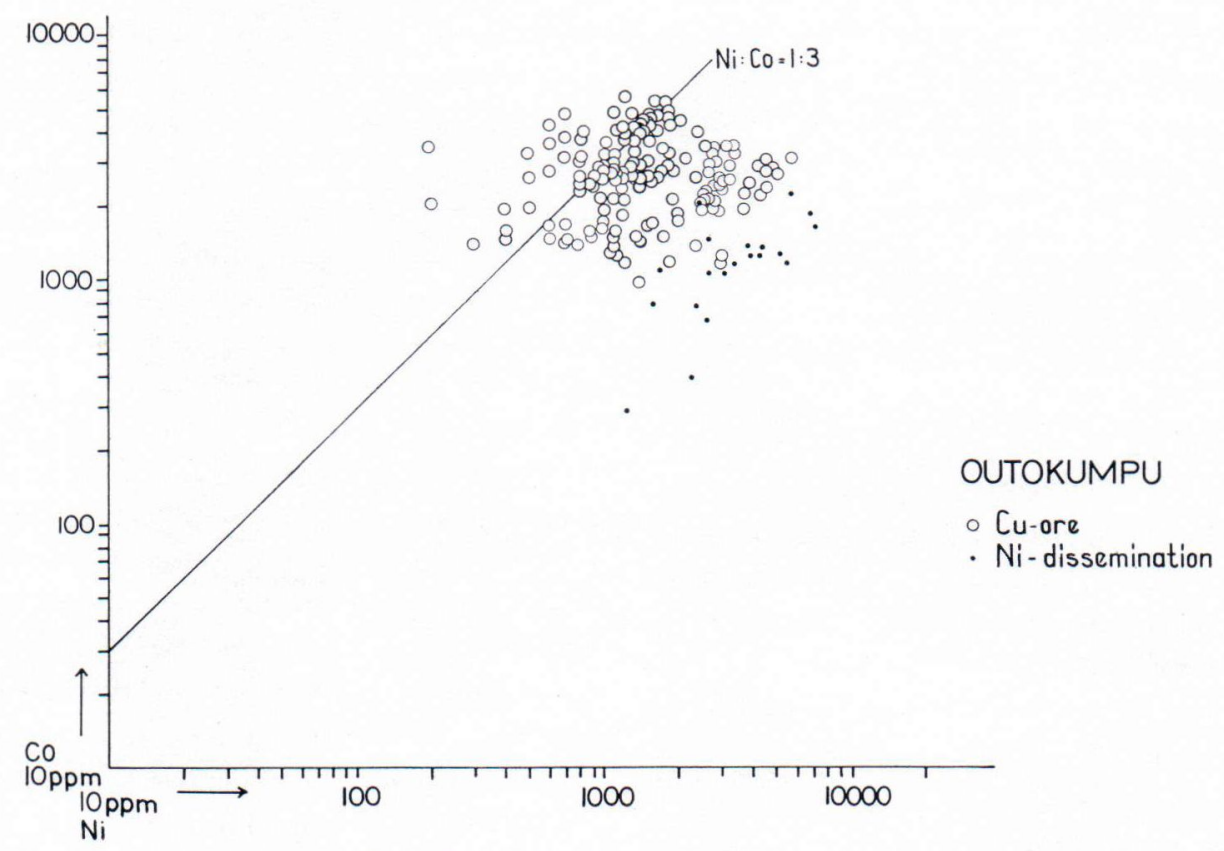

Fig. 23. Ni-Co diagram. Outokumpu.

SW half and right from the NE end of the orebody (Fig. 22). In addition there is analytical information from separate nickel mineralisations located above the actual orebody at the SW end of it (Vähätalo, 1953, pp. 74-75).

$\mathrm{Ni}-\mathrm{Co}$ and $\mathrm{Cu}-\mathrm{Co}$ diagrams as well as $\mathrm{Cu}-$ $\mathrm{Co}-\mathrm{Ni}$ triangular diagram were drawn on the basis of the forementioned analytical data. The points in the diagrams represent the mean contents in the ore blocks and not individual analyses as in the other diagrams of this paper.

In the Ni-Co diagram (Fig. 23) the area occupied by the points representing ore is relatively extensive. In some cases the nickel content in the ore is low, only c. $200 \mathrm{ppm}$, but in some it is rather high, up to $5000 \mathrm{ppm}$. The cobalt content averages between 1000 and $5500 \mathrm{ppm}$, being most often $2000-4000$ ppm.

There are some groupings of points in the diagram of which the nickel-rich (over $2000 \mathrm{ppm}$ $\mathrm{Ni}$ ) groups represent the $\mathrm{SW}$ end and NE tip of the orebody. The areas poorer in nickel predominate in the central parts of the orebody.
The mineralised portions outside the ore body proper are poorer in sulphides (under 10 per cent S) than the ore (15-30 per cent S). Nevertheless the nickel content is remarkably high, 1500 $6500 \mathrm{ppm}$, most often $2500-4000 \mathrm{ppm}$. The cobalt tenor varies from 400 to $2000 \mathrm{ppm}$, usually being $1000-1500 \mathrm{ppm}$.

In the $\mathrm{Cu}-\mathrm{Co}$ diagram (Fig. 24) the copper content of the ore points varies between 1.3 and 8 per cent. The points representing mineralisations contain several thousand ppm of copper.

Due to the abundance of copper the ore points in the $\mathrm{Cu}-\mathrm{Co}-\mathrm{Ni}$ triangular diagram (Fig. 25) are naturally near the $\mathrm{Cu}$-apex of the triangle. Most of the points are in one group representing $91-93$ per cent copper, 5-7 per cent cobalt and $1-3$ per cent nickel. The ratio of nickel to cobalt is c $1: 3$.

In the diagram this field forks into three parts. In some cases, when the ore has a very high copper content, the relative amount of copper may even rise as high as 96 per cent and an extension from the point grouping approaches the $\mathrm{Cu}$-apex 


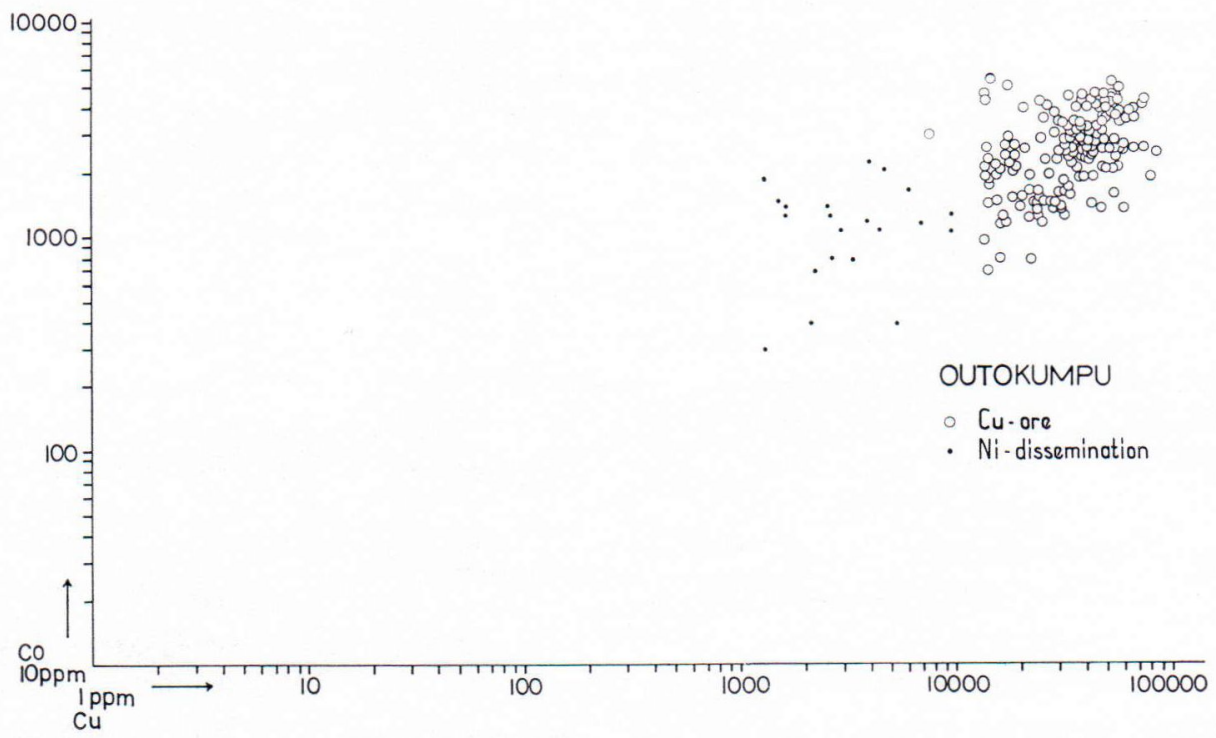

Fig. 24. $\mathrm{Cu}-\mathrm{Co}$ diagram. Outokumpu.

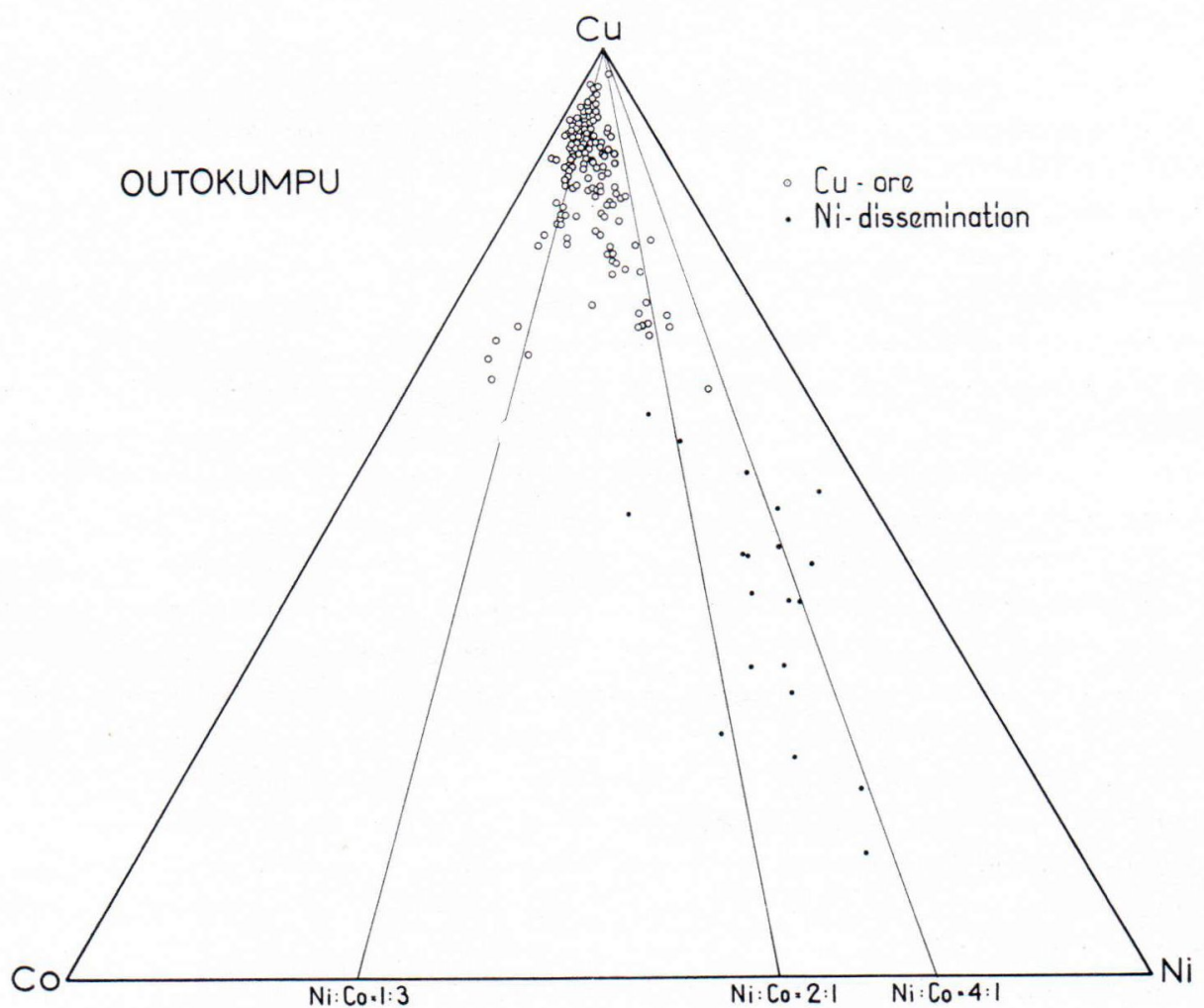

Fig. 25. $\mathrm{Cu}-\mathrm{Co}-\mathrm{Ni}$ triangular diagram. Outokumpu. 
of the triangle. On the other hand when the copper content drops a succession of points is formed in the opposite direction towards the $\mathrm{Co}-\mathrm{Ni}$ side of the triangle. The third fork approaches the $\mathrm{Ni}$-apex of the triangle. In that case, the relative amount of copper decreases while the ratio of nickel to cobalt becomes continuously more nickel-predominant, reaching values as high as $2: 1$.

The mineralised portions in the diagram form an extension to the latter. The relative amount of copper drops considerably, down to $15-20$ per cent, and the ratio of nickel to cobalt becomes nickel-predominant, c. $4: 1$ (occasionally even $10: 1)$.

The foregoing findings concerning the Outokumpu ore do not bring anything essentially new to the conception formed on the basis of the other copper-cobalt ores. The distribution of copper, cobalt and nickel is similar for all of them.

If the Ni-Co diagrams (Figs. 9, 12 and 23) and the $\mathrm{Cu}-\mathrm{Co}-\mathrm{Ni}$ triangular diagrams (Figs. 18-21 and 25) are examined in detail, it becomes evident that the large Outokumpu ore in fact represents all the other ores described. Its various parts contain areas which are comparable with the other deposits.

In places the Outokumpu ore is poor in nickel (e.g. where the Kumpu and Lietukka orebodies overlap, Fig. 22). It is rich in cobalt and very similar to the Riihilahti deposit when the nickel to cobalt ratio is c. $1: 5$ or even less (Figs. 12 and 23).

In the Lietukka orebody of the Outokumpu deposit a gradual increase in the content of nickel can be observed towards SW. Simultaneously the contents of copper and cobalt decrease somewhat. Consequently the ratio of nickel to cobalt increases. There are portions in the ore comparable e.g. with the deposits at Vuonos and Hietajärvi (Figs. 19 and 20).

The Outokumpu nickel mineralisations are very similar in character to the quartzite-skarn-dolomites which in this paper have been called anomalous in respect to cobalt and which in places show considerable nickel concentrations (Figs. 9, 23 and 24). The nickel-predominant SW-tip of the Outokumpu ore is also similar but richer in copper than the nickel mineralisations.

The Outokumpu ore differs from the other deposits in that it contains pyrite as well as pyrrhotite. The pyrite is cobalt-bearing and, apart from cobalt pentlandite, is the only significant carrier of cobalt in the Outokumpu deposit.

\section{Summary}

In North Karelia, the known copper-cobalt ores are usually associated with serpentinitequartzite formations similar to the Outokumpu zone. One exception exists so far, the Riihilahti deposit in which the ore is embedded in mica gneiss.

The serpentinite-quartzites contain about 0.2 per cent nickel. In the areas where these rocks are not associated with copper-cobalt ores or mineralisations, the nickel to cobalt ratio is similar to that in the ultramafic rocks (Häkli, 1963) and varies from $20: 1$ to $25: 1$. The abundance of cobalt is about 0.01 per cent and that of copper even less than that, i.e. only a few ppm.

The relative abundances of the three metals are such that the percentage of nickel is 95 , that of cobalt between 4 and 5 and that of copper only a few tenths.

Black schists and mica gneisses are poorer in nickel and cobalt than serpentinite-quartzites. On the other hand, the former are richer in copper than the latter. The average content of nickel in black schists is 0.03 per cent and of cobalt and copper 0.003 per cent and 0.02 per cent, respectively. The corresponding concentrations in mica gneisses are 0.006 per cent $\mathrm{Ni}, 0.002$ per cent $\mathrm{Co}$ and 0.006 per cent $\mathrm{Cu}$. Thus, the nickel to cobalt ratios in the black schists and mica gneisses are lower than in the serpentinite-quartzite assemblages. 
Whenever copper-cobalt ores occur in serpentinite areas the sulphides associated with the ores produce changes in the normal abundances and ratios of $\mathrm{Ni}, \mathrm{Co}$ and $\mathrm{Cu}$ in the country rocks.

The anomalies manifest themselves in two ways:

1. The abundance of cobalt in a rock increases more than usual without any significant change in the nickel content. As a consequence, the nickel to cobalt ratio is reduced. Changes of various degrees are encountered ranging from the normal nickel to cobalt ratios to those of the copper-cobalt ores. In the latter, cobalt usually predominates over nickel.

2. Simultaneously with the increase in the cobalt tenor, the rock also acquires some extra copper. The abundances of copper and cobalt does not increase parallel to each other, for while the copper tenor increases 200 -fold from the normal value to that in the ore, the abundance of cobalt is only increased 20 -fold.

Similar anomalies are also produced by coppercobalt ores in black schists etc.

It seems that the environment and the size of the orebody have an effect on the nickel to cobalt ratio in the copper-cobalt ores. A small orebody in association with a large serpentinitequartzite occurrence (Sola) is nickel-predominant $(\mathrm{Ni} / \mathrm{Co}=5: 1)$, whereas a larger orebody in a similar environment (Vuonos, Outokumpu) shows a predominance in cobalt $(\mathrm{Ni} / \mathrm{Co}=2: 3$ -1:3). Should the nickel environment be lacking (Riihilahti), the ore (even a small one) contains more cobalt than nickel $(\mathrm{Ni} / \mathrm{Co}=1: 5)$.
The nickel to cobalt ratio in the rocks is also reflected in the nickel to cobalt ratio in pentlandite. Pentlandite, which is the principal carrier of nickel and cobalt, is nickel pentlandite in serpentinites and quartzite-skarn-dolomite assemblages. Parallel to the increase in the anomalous cobalt, the abundance of cobalt increases in pentlandite. The pentlandites richest in cobalt are encountered in copper ore.

In places nickel mineralisations $(\mathrm{Ni}>0.3$ per cent) are encountered in quartzite-skarn-dolomites. Two shades of mineralisation occur. In some locations nickel has been enriched at the contact of black schists, in which case the mutual ratios between the abundances of nickel, cobalt and copper are of the same order of magnitude as those in serpentinite-quartzites in general. In some other places the mineralisations occur as sulphide concentrations in anomalies produced by copper-cobalt ores. Occasionally similar nickel mineralisations are also met with at the margins of the copper-cobalt orebodies against serpentinite-quartzites. In these cases the mutual ratios between nickel, cobalt and copper vary, approaching to those of the anomalous rocks (in respect to cobalt and copper).

Acknowledgements - The authors wish to express their cordial thanks to Dr. Paavo Haapala, chief geologist of the Outokumpu Company, for the interest, encouragement and criticism he has shown towards this study.

The chemical analyses were made in the Geochemical Laboratory of the Exploration Department of the Outokumpu Co under the supervision of Dr. Heikki Wennervirta.

The manuscript was translated into English by Mrs. Gillian Häkli. Dr. T. A. Häkli offered assistance in the editorial work. To all these persons the authors would like to record their appreciation.

\section{REFERENCES}

Aubouin, Jean (1965) Geosynclines, Developments in geotectonics 1. Elsevier, Amsterdam.

Frosterus, B. and Wilkman, W. W. (1920) Vuorilajikartan selitys, Lehti D 3, Joensuu. Suomen geologinen yleiskartta, 1:400 000. Geologinen toimikunta, Helsinki.
GAÁL, GABOR (1964) Jatul und karelische Molasse im S-Koligebiet in Nordkarelien und ihre Beziehungen zum Gebirgsbau des präkambrischen Orogens. Bull. Comm. géol. Finlande 213.

HaApala, PaAvo (1936) On serpentine rocks in Northern Karelia. Bull. Comm. géol. Finlande 114. 
Hackman, Victor (1914) Über Camptonitgänge im mittleren Finnland. Bull. Comm. géol. Finlande 42.

Häkli, Aulis (1963) Distribution of nickel between the silicate and sulphide phases in some basic intrusions in Finland. Bull. Comm. géol. Finlande 209.

Kouvo, Olavi (1958) Radioactive age of some Finnish pre-Cambrian minerals. Bull. Comm. géol. Finlande 182.

- and Vuorelainen, Yrjö (1958) Eskolaite, a new chromium mineral. Am. Min. 43, p. 1098.

- , Huhma, Maija and Vuorelainen, YRjö (1959) A natural cobalt analogue of pentlandite. Am. Min. 44, p. 897.

- , Vuorelainen, Yrjö and Long, J. V. P. (1963) A tetragonal iron sulphide. Am. Min. 48, p. 511.

Peltola, Esko (1960) On the black schists in the Outokumpu region in Eastern Finland. Bull. Comm. géol. Finlande 192.
- (1967) Outokummun kaivoksen malmiarvio. Report in the archives of the Outokumpu Co.

Thayer, T. P., Milton, Charles, Dinnin, Joseph and Rose, Harry (1964) Zincian chromite from Outokumpu, Finland. Am. Min. 49, p. 1178.

Weiser, Thorolf (1967) Zink- und Vanadium-führende Chromite von Outokumpu/Finnland. Neues Jahrb. Miner. Mh. p. 234.

Vähätalo, Veikкo (1953) On the geology of the Outokumpu ore deposit in Finland. Bull. Comm. géol. Finlande 164.

VäYRYNEN, HeIKKI (1939) On the geology and tectonics of the Outokumpu ore field and region. Bull. Comm. géol. Finlande 124.

Manuscript received, July 4, 1969. 